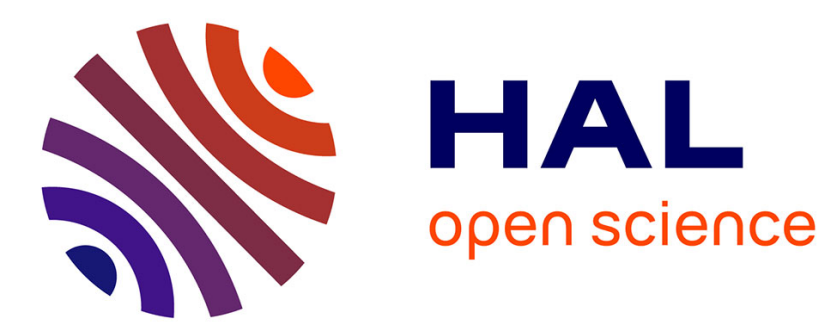

\title{
Constitutional Judicial Behavior: Exploring the Determinants of the Decisions of the French Constitutional Council
}

Romain Espinosa

\section{- To cite this version:}

Romain Espinosa. Constitutional Judicial Behavior: Exploring the Determinants of the Decisions of the French Constitutional Council. Review of Law and Economics, 2017, 13 (2), 10.1515/rle-20150034 . halshs- 01634213

\section{HAL Id: halshs-01634213 \\ https://shs.hal.science/halshs-01634213}

Submitted on 14 Nov 2017

HAL is a multi-disciplinary open access archive for the deposit and dissemination of scientific research documents, whether they are published or not. The documents may come from teaching and research institutions in France or abroad, or from public or private research centers.
L'archive ouverte pluridisciplinaire HAL, est destinée au dépôt et à la diffusion de documents scientifiques de niveau recherche, publiés ou non, émanant des établissements d'enseignement et de recherche français ou étrangers, des laboratoires publics ou privés. 


\title{
Constitutional Judicial Behavior: Exploring the Determinants of the Decisions of the French Constitutional Council
}

\author{
Romain Espinosa*
}

April 20, 2015

\begin{abstract}
This article empirically assesses the relevance of three theories of judicial decisionmaking for the French Constitutional Council. Our empirical analysis follows previous works by integrating more recent observations, and proposes a new methodology by exploiting new data for cases post 1995. After analyzing the 612 cases published between 1974 and 2013, we focus on cases post 1995 for which we know the exact composition of the court. Our results suggest that (1) political/ideological voting occurs, (2) Justices restrain themselves from invalidating laws, and (3) a court's independence suffers from political power concentration in other institutions. All in all, these results suggest the need for a reform of the Constitutional Council to strengthen its independence.
\end{abstract}

keyword constitutional court, attitudinal model, judicial self-restraint, opportunistic independence, judicial decision-making, politicization, judicial independence.

*CRED, Université Paris 2 Panthéon-Assas, 12 place du Panthéon, 75005 Paris, France. Email: romain.espinosa@u-paris2.fr

JEL Codes: D71, D72, K40

Adknowledgements I am indebted to Bruno Deffains and George Bresson for multiple readings, and their thorough and insightful remarks. I am also very grateful to Dominique Schnapper, Lee Epstein, Nuno Garoupa, Jeffrey Rachlinski, Jerg Gutmann, Sofia AmaralGarcia, Pierre Bentata and two anonymous referees for their detailed and very helpful remarks on previous versions of this paper. 


\section{Introduction}

In the past two decades, a growing empirical literature has analyzed the determinants of Supreme Court rulings. These studies started from the widespread observation that Justices do not decide solely on legal grounds, but are also influenced by personal, inter-personal and out-of-court matters. These studies have explored numerous theories of judicial decisionmaking. The goal of this paper is to assess the relevance of three of them for the French Conseil Constitutionnel.

First of all, a considerable number of empirical investigations have aimed at determining whether judges are influenced by political or ideological factors when deciding a case. These works have mainly sought to question the relevance of the Kelsenian theories of courts supported by legalists, who state that judges decide purely on legal grounds. These legalist views follow a very long tradition in civil law countries, which usually consider that law-making is done exclusively by the Parliament, and that courts rule in a very narrow interpretive framework. In Montesquieu's words, legalists typically consider judges to be the "mouth of the law", who must stick to statutory provisions when enforcing the law. Many studies in the United States have been conducted during recent decades, and have emphasized, contrary to the legalist theory prediction, that ideological beliefs and political matters influence Justices' decisions (Epstein et al. (2007), Martin et al. (2005), Spiller and Gely (1992), Epstein and Landes (2012), Epstein and Martin (2012)). Similar studies have been conducted for European Constitutional Courts, i.e. in civil law countries, and have tended to support a similar conclusion: Justices are less likely to strike down laws passed by the party that appointed them (Amaral-Garcia et al. (2009), Garoupa et al. (2011), Hoennige (2009)). More globally, these studies have contributed to validating the attitudinal theory, which claims that Justices are motivated not only by legal concerns, but also by political and ideological matters.

A second branch of research has explored the existence of judicial self-restraint, that is to say Justices' reluctance to strike down laws voted by the Parliament. Judge Posner defined the judicial self-restraint theory as: "the reluctance of judges to declare legislation or executive action unconstitutional out of deference to the judgements of the elected branches of government". ${ }^{1}$ Judicial self-restraint may therefore occur whatever the political and/or ideological considerations of the Justices. Politically indifferent Justices may also be subject to judicial self-restraint: even Justices who leave aside their political views may be reluctant to invalidate laws passed by elected representatives. This aversion against invalidation might be driven either by personal preferences (weak perception of the Constitutional Court's legitimacy), or by social concerns (Constitutional Courts are not expected to invalidate bills passed by elected representatives). Judicial self-restraint is especially relevant in the French case, where there exists a well-established tradition against judicial activism. Following Montesquieu, French legal scholars and politicians often publicly criticize decisions of the judiciary when they fill a legislative gap. In the American case, Epstein and Landes (2012) aimed at disentangling judicial self-restraint from ideological voting, but found no evidence for judicial self-restraint.

At last, a third category of studies has analyzed the role of political division in exerting

\footnotetext{
${ }^{1}$ As quoted in Epstein and Landes (2012).
} 
institutional pressure on Supreme Courts' decisions. From a theoretical perspective, Lijphart (1999) claimed that Supreme Courts are more likely to function properly in consensual than in majoritarian democracies. To his view, institutions in majoritarian systems exist to serve the interests of the political majority, unlike those in consensual democracies, which seek to maximize the support for public policies. Lijphart predicts therefore that a higher degree of power concentration in majoritarian democracies will induce a stronger pressure of the majoritarian party on other institutions. According to this theory, Supreme Courts would be less likely to function properly when power is concentrated. On the contrary, when elected branches are politically divided, the theory predicts that Supreme Courts are more likely to arbitrate between majorities, and therefore to fulfill their duty of constitutional review. Garoupa and Grembi (2013) analyzed the shift from a consensual to a majoritarian democratic system, and report some evidence for a change in the role played by the Supreme Court in line with Lijphart's theory. In the same direction, Franck (2009) investigates whether the division of political power in French elected institutions affects the likelihood of censorship by the Constitutional Council.

In addition to these three lines of research, the present paper proposes to contribute to a growing literature on judicial behavior (Carroll and Tiede (2011)). Judicial independence has been extensively discussed in the past decades, since economists have argued that economic growth is fostered when litigants are confident in the independence of the legal system (Holcombe and Rodet (2012)). La Porta et al. (1999) argued that differences in economic growth between civil law and common law countries were mainly explained by the lack of judicial independence in civil law countries. Aside from the civil law vs. common law debate, Feld and Voigt (2003) showed that de jure judicial independence does not matter for economic growth, but that de facto judicial independence does. Hayo and Voigt (2007) showed, however, that institutional provisions remain the most important determinants of de facto judicial independence. Serious doubts have therefore been raised about de jure judicial independence in institutional frameworks, where the judiciary and the political branches are too interconnected. Melton and Ginsburg (2014) find indeed that judicial independence is enhanced when both the selection and the removal processes of judges ensure that they are independent from other political actors. In the Japanese case, Ramseyer and Rasmusen (1997) showed indeed that the hierarchical structure of the judiciary, together with the political appointment process of the Supreme Court's Justices, can create great threats to judicial independence.

The aim of this paper is to investigate the extent to which the three preceding theories apply to the French case. In the following analysis, we shall refer to the attitudinal model when the outcome of the decisions of the Constitutional Council (CC) depends on the political and ideological linkages between Justices and other political actors. Moreover, we will call the judicial self-restraint theory the fact that Justices limit their censorship decisions because they are reluctant to strike down laws voted by elected branches. Finally, we shall refer to the opportunistic independence theory when the CC's independence is greater when institutions are politically divided. Here, we understand judicial independence as "the amount of discretion that judges have at their disposal vis-à-vis representatives of other government branches" (Feld and Voigt (2003)). 
From a pragmatic perspective, the attitudinal model usually implies that the likelihood of invalidating a law is decreasing with the number of Justices who were appointed by the government's party. The judicial self-restraint theory typically entails the idea that Justices are less likely to invalidate a law if they have already recently stricken down laws. With regard to the opportunistic independence theory, a natural consequence is that the CC invalidates more laws when other institutions are politically divided.

These three theories are a priori highly relevant for the French case. Regarding the attitudinal model, the CC is indeed frequently criticized for its (assumed) political activism. The recent opposition between the socialist government and the President of the CC, a former right-wing politician, is representative of the accusations of political / ideological voting against the CC. ${ }^{2}$ Moreover, the French legal tradition is characterized by a well-established deference of the judiciary to the elected bodies: following Montesquieu, legal scholars believe that courts should not engage in law-making, and should stick to a strict enforcement of laws. This deference is regularly expressed by Justices themselves, who claim to resist the international trend of a uniformization of constitutional courts toward the American system. ${ }^{3}$

The two closest studies to our work are Franck (2009) and Franck (2010). Studying the French Constitutional Council's rulings, Franck (2009) has shown that the level of independence of the Constitutional Council is higher when institutions are politically divided. This work has also shown some evidence suggesting that Justices without a legal background may engage in political/ideological voting. Franck (2010) also found that the Constitutional Council's decisions on contested elections were additionally affected by political/ideological considerations: far-right candidates are, ceteris paribus, more likely to have their elections invalidated. Our study builds on these two previous works, and completes them in three ways. First, the current paper proposes to consider a broader framework of decision-making: we test the relevance of three theories at the same time (the attitudinal model, opportunistic independence theory and the judicial self-restraint theory). Franck (2009) devoted his attention to the two first theories. Second, our dataset includes more recent data: while Franck (2009) considered decisions up to 2006, our investigation deals with all cases from 1974 to 2013. Third, we exploit a new source of information on the data to better assess the impact of political/ideological voting. Our results complete and strengthen the previous findings of Franck (2009) and Franck (2010).

To answer these research questions, we construct a dataset that comprises all CC's rulings from 1974 to 2013 (August). ${ }^{4}$ We then run a series of logit estimations, including fixed effect specifications. We also explore the time component of our observations. The empirical investigation tends to confirm that the three theories have some relevance for the French case: Justices seem to be more likely to support laws passed by the party that appointed them; Justices are reluctant to invalidate too many laws; and the CC is more likely to strike down a law when institutions are politically divided.

\footnotetext{
${ }^{2}$ http://www.lemonde.fr/politique/article/2014/01/06/le-rappel-a-l-ordre-de-jean-louis-debre-a-lexecutif_4343687_823448.html (Last Access: April, 2015)

${ }^{3}$ http: / / www.lepoint.fr/politique/conseil-constitutionnel-jospin-oppose-a-l-idee-d-une-cour-supremefrancaise-15-12-2014-1889977_20.php (Last Access: April, 2015)

${ }^{4} \mathrm{~A}$ few cases were dropped, either because the CC declared that it was not empowered to rule on them, or because they were constitutional revisions.
} 
The rest of the paper is organized as follows. Section 2 presents the CC and the data. Section 3 presents the empirical strategy. Section 4 displays the results. Section 5 discusses the implications of our results. Section 6 concludes.

\section{The Conseil Constitutionnel}

\subsection{Description of the Conseil Constitutionnel}

The Conseil Constitutionnel was created together with the Fifth Republic (1958). The regular part of the Constitutional Council is composed of 9 Justices renewable per third and appointed for 9 years. Every three years, three Justices leave the CC; the President of the Republic and each President of the two Chambers appoints one Justice each for nine years. The President of the Constitutional Council is designated by the President of the Republic among the Justices sitting at the CC. Justices can be appointed only once for a full mandate (9 years), but those who are appointed to replace a Justice who left the bench before the end of his/her mandate can be reappointed for one full mandate. Between 1974 and 2013, four Justices were appointed twice according to this procedure. ${ }^{5}$ In addition to the nine regular Justices, former Presidents of the Republic may sit as ex-officio members when they desire to do so. In practice, these members have had a limited role in the CC's decisions. ${ }^{6}$

The Constitutional Council was the first institution empowered to substantially review laws. $^{7}$ The 1958 Constitution gave the $\mathrm{CC}$ the power to review laws in abstract, i.e. after the vote of the Parliament and before their promulgation by the President of the Republic. Until 1974, judicial review had to be requested either by the President of the Republic, the Prime Minister, the President of the Senate (Upper Chamber) or the President of the National Assembly (Lower Chamber).

Two main constitutional reforms have contributed to changing this institutional framework. The 1974 constitutional reform has extended requests for judicial review to Deputies and Senators. In fact, this reform has introduced for major opposition parties the possibility to challenge laws passed by the majority. 8 Since then, the CC has gained importance, and abstract judicial review has been extensively used by the opposition. The 2008 reform

\footnotetext{
${ }^{5}$ Joxe was first appointed to end Rey's mandate, and was then appointed for a full mandate. He was seated for 12 years at the CC. Lecourt was called to replace Coste-Floret, and was then appointed for a complete mandate. He sat for 10 years. Bazy-Malaurie was first appointed in 2010 to carry on Pezant's mandate, and she was reappointed in 2013. Finally Simonnet was appointed twice (once for replacement, and once for a full mandate), but died before the end of his mandate. He sat about 4 years at the CC.

${ }^{6}$ Three former Presidents of the Republic (De Gaulle, Pompidou, Mitterrand) did not sit at the Council at all. Chirac took part in a few decisions for a limited time period, since he had to retire for health reasons. Sarkozy has not taken part in abstract review so far (but did for concrete review). All in all, only Giscard d'Estaing has attended the Council on a regular basis since the end of his presidential mandate.

${ }^{7}$ The fourth Republic created an institution able to strike down laws only if procedures had been violated.

${ }^{8}$ Requests by parliamentarians must be done jointly. In fact, Deputies and Senators must have at least 60 in their own Chamber to ask the CC to challenge a law. However, considering that the National Assembly comprises more than 500 seats, this requirement has been set low enough to ensure that major opposition parties are always able to meet the criterion.
} 
introduced the possibility of concrete judicial review. Since that date, the CC has been able to strike down laws which are already in force if litigants contest their constitutionality during a trial (Questions Prioritaires de Constitutionnalité). This procedure has become very popular in the past few years, which has considerably increased the power - and the amount of work- of the CC.

In the rest of this article, we shall focus solely on abstract reviews, which are called décisions constitutionnelles. We shall refer to these rulings as decisions. Invalidation decisions may concern only some specific features of the laws at stake. The distinction between partial validation and partial invalidation is not our concern, since we consider the outcome of the decision as reported by the $\mathrm{CC}$ itself. Because of the very small number of partial validations, this is however not a concern. We categorize the CC's decisions as either conformity decisions or censorship decisions.

The main institutional difference between the French $\mathrm{CC}$ and other Constitutional Courts lies in the fact that the debates of the $\mathrm{CC}$ are private, and, therefore, neither individual votes nor individual opinions are available. Privacy of the deliberations is also applied at the Italian Constitutional Court, and is motivated by the will to reinforce the legitimacy and the strength of the Court's decisions.

\subsection{Data}

To analyze the determinants of the CC's decisions, we construct a dataset that comprises the entire set of decisions from 1974 to 2013 excluding one constitutional revision and a few cases where the $\mathrm{CC}$ was not competent. The final dataset contains 612 cases. The choice to focus on decisions made after 1974 is due to the substantive changes introduced by the 1974 constitutional reform.

The dataset contains information about decisions on laws that were passed either under left-wing or under right-wing legislatures. During this time period, France has been ruled by six right-wing legislatures and four left-wing coalitions. ${ }^{9}$ Our investigation focuses solely on the so-called décisions constitutionnelles, that is to say judicial review of laws voted by the Parliament but not yet promulgated by the President of the Republic. It includes regular bills, organic laws, resolutions, and treaties. For each decision, we collected both information about the content of the decision and information about the challenged law. Table 4 summarizes variables of our dataset.

First, regarding information about the decision itself, we define a censorship variable, which is equal to 1 when the decision is reported as non-conformité (invalidated) and equal to 0 when the decision is reported as conformité (conforms to the Constitution). ${ }^{10}$ We create a series of variables about the political context in which the decision is made: the proportion of Justices appointed by a right-wing party who are supposed to attend the decision ( comp $R W$ ),

\footnotetext{
${ }^{9}$ For right-wing legislatures: 1973-1978, 1978-1981, 1986-1988, 1993-1997, 2002-2007, and 2007-2012. For left-wing legislatures: 1981-1986, 1988-1993, 1997-2002, and 2012-present.

${ }^{10}$ The CC also has the power to validate a law, and to give some guidelines for the interpretation of this law. This is called interprétation avec réserves. While this legal tool may have some importance, this is not the focus of our article, since these guidelines usually clarify the original goal of the government.
} 
a dummy variable for the fact that the Chief Justice was appointed by a right-wing party (presRW), a dummy variable if the Senate's majority is aligned with the National Assembly's majority (senate), and a dummy variable if the Prime Minister is not from the same party as the President of the Republic (cohabitation). We also indicate whether the previous decision made by the $\mathrm{CC}$ was an invalidation decision (previous), the number of invalidation decisions since the beginning of the parliamentary session (parliamentary), a dummy variable that accounts for the fact that other invalidation decisions have been published on the same day (sameDay $)^{11}$, and the time the $\mathrm{CC}$ took to review the law (delay). Moreover, we control for the authority which asked for the review (senators, joint, presRep, primeMin, presSenate, presAssem).

Second, we also collect information about the challenged law. We create a series of dummy variables which account for the area of the challenged law (economics, electoral, finances, institution, justice and territorial). We categorize each challenged law into four groups and create corresponding dummy variables: regular statutes (reference group), organic laws (organic), resolutions (resolution) and treaties (treaty).

Third, we create additional variables for the 1995-2013 time period. For this time period, we are indeed able to disentangle exactly which Justices attended the decision. We exploit these case-to-case variations to create three variables. First, we compute the exact share of Justices appointed by right-wing parties over the set of all appointed Justices (share $R W$ ). We are therefore able to replace comp $R W$ by the more precise variable share $R W$ for the subset of laws passed between 1995 and 2013. Second, we create two variables that account for the presence of the two former Presidents of the Republic (giscard and chirac). ${ }^{12}$

Our main variable of interest is censorship. As we mentioned above, the classification of the decisions as validation or censorship is achieved by the CC itself. ${ }^{13}$ As one can see in table 3, the number of decisions per legislature has remained relatively stable from the end of the 70s until the beginning of the 2000s. In the two past legislatures (2002-2007 and 20072012), the number of decisions has increased (from 70-80 to 90-100 decisions per five year legislature). This increase in the work of the $\mathrm{CC}$ is mainly due to the CC's growing political role. In fact, in past decades, opposition parties have become more and more prompt at challenging laws before the CC as a last attempt to block the government's projects.

More interestingly, the rate of censorship has considerably varied across legislatures. The highest censorship rate was found during Jospin's legislature (58.2\%). The fact that this high censorship rate occurred during a cohabitation period would tend to support the opportunistic independence theory. In French politics, cohabitation refers to legislatures during which the President of the Republic and the Prime Minister are not from the same political wing. Franck (2009) has found that censorship rates were higher under cohabitation

\footnotetext{
${ }^{11}$ The Constitutional Council sometimes issues several decisions on the same day. The variable sameDay counts the number of other invalidation decisions made on the same day.

${ }^{12}$ As we show in the appendix, former Presidents potentially select cases they attend. To avoid selection problems and to distinguish their role from the behavior of appointed Justices, we include these two dummy variables in the set of controls for 1995-2013 decisions.

${ }^{13}$ The decisions can either be: total validation, partial validation, partial censorship, or total censorship. Since partial validation and total censorship concern less than $5 \%$ of the cases, we consider only two categories: validation and censorship.
} 
(for the subsample of left-wing legislatures only).

Note however that cohabitation cannot be the only factor accounting for the high censorship rates. In fact, one can see that the second highest censorship rate was found under Sarkozy's presidency, where the Prime Minister was from the same party. Moreover, the 1986-1988 right-wing legislature, which was also a cohabitation phase, reported a relatively low censorship rate $(43.2 \%)$.

All in all, these results suggest that legislatures may have been heterogenous in the quality of laws they produced, inducing de facto different censorship rates.

For an overview of the database, table 5 displays the summary statistics of the variables listed in table 4. Several remarks can be made in the light of these numbers. First, one can note that the censorship rates are roughly constant across left-wing and right-wing legislatures. Second, we observe that the average proportion of Justices appointed by right-wing parties is higher under right-wing legislatures than under left-wing legislatures. This comes from the fact that, when a party wins the elections, it appoints its own Justices in the years following its election. Third, it can be mentioned that, according to the subsample we consider, the most frequent kind of request is either the joint request (when both 60 senators and 60 deputies ask for judicial review) or the request by 60 deputies only. In the econometric investigation, we will take requests by 60 deputies as the reference group.

In the appendix, we propose a discussion about the potential time components that may affect our regressions. We show the necessity to include a linear time trend in our analysis.

\section{Empirical Strategy}

We now turn to the empirical investigation of the CC's decisions from 1974 to 2013. Our econometric strategy consists of a series of logistic regressions that aim to explain censorship decisions ( 0 if validation, 1 if censorship) in the light of the three theories discussed above.

Four categories make up our independent variables: variables for each of the three theories on judicial decision-making presented above, and control variables. Discussion of the expectations implied by the three theories that we aim to test is summarized in table 1 .

Attitudinal Model First, we include variables that account for ideological or political voting. To assess the relevance of the attitudinal theory, we include several variables.

If Justices vote on a political or ideological basis, we can expect the proportion of Justices appointed by a right-wing party to increase the censorship probability of laws passed by leftwing coalition. Conversely, we can expect it to have a negative impact on the invalidation likelihood of laws passed under a right-wing legislature. To capture this phenomenon, we include in our set of regressors the proportion of Justices appointed by right-wing parties (compRW for the full set of decisions, share $R W$ for the 1995-2013 subperiod), and an interaction term with a dummy variable for right-wing laws $\left(\mathbb{1}_{\text {Right }}\right)$. The attitudinal model predicts that this interaction term will be significant and negative: the more Justices appointed by right-wing parties hear a case, the less likely a right-wing law will be censored. 
Another prediction of the attitudinal model concerns the role played by the Chief Justice. If the Chief Justice is also affected by political or ideological concerns, it may be that he uses his authority to favor laws of the party that appointed him/her. To capture this second effect, we include in our set of explanatory variables a dummy variable whether the Chief Justice was appointed by a right-wing party (presRW) and an interaction term with the dummy variable for right-wing laws $\left(\mathbb{1}_{\text {Right }}\right)$. If the attitudinal model holds, we expect the interaction term to be significant and negative (right-wing laws are less likely to be invalidated when the Chief Justice was appointed by a right-wing party).

Judicial Self-Restraint Second, we propose to test the relevance of the judicial selfrestraint theory in three ways. In a first step, we propose to investigate whether a previous decision has an impact on the censorship likelihood. Indeed, if Justices wish to refrain from invalidating too many laws, they will avoid censoring a law when their last decision was already an invalidation. To capture this phenomenon, we include previous in our set of explanatory variables. If the coefficient associated with this variable turns out to be negative, it will mean that Justices are reluctant to invalidate a law when their last decision was already a censorship decision.

A second way to test the validity of the judicial self-restraint theory is explained by Schnapper (2010). In her testimony regarding her stay at the CC, she mentions the existence of a censorship quota per parliamentary session, meaning that Justices are reluctant to invalidate a law if they have already invalidated many laws in the parliamentary session. ${ }^{14}$ Following this statement, we propose to test for the significance of the number of censorship decisions since the beginning of the parliamentary session (parliamentary) on future decisions. This variable aims to represent the pressure described by Schnapper. The judicial self-restraint theory predicts a negative coefficient associated with this variable: the more laws that Justices have censored previously in the parliamentary session, the less likely they will be to censor future laws of the same parliamentary session.

A third method aimed at testing the judicial self-restraint theory consists in looking at the effects of invalidation on decisions issued on the same day. Indeed: in some cases, the CC can deliberate, and then publish several decisions on the same day. Following the judicial self-restraint theory, one could hypothesize that self-restrained Justices would be reluctant to censor too many laws on the same day. This would result in a negative dependence across decisions given the same day: the more laws that the Justices have already censored in other decisions, the less likely they will be to invalidate the law at stake. The judicial self-restraint theory predicts therefore a negative and significant coefficient associated with the sameDay variable.

Opportunistic Independence Third, following previous works on the French CC, we propose two ways to test whether the CC invalidates more laws when the polity is divided. To begin with, our set of independent variables includes a dummy variable, which accounts

\footnotetext{
14"A Chief Justice declared once with humor that the Council had run out of censorship decisions for the year or the parliamentary session, and, therefore, could not afford any additional one [...]" (In French: "Un président avançait parfois, avec humour, que le Conseil avait épuisé son 'quota' de censure pour l'année ou pour la session parlementaire en cours, qu'il ne pouvait plus se permettre d'en imposer une nouvelle [...]") (p.256) Schnapper (2010).
} 
for the fact that the Senate's majority is aligned with the National Assembly's majority (senate). Following the opportunistic independence theory, we expect this variable to have a negative coefficient, meaning that the censorship rate decreases when the polity is united (i.e. the two Chambers support the government).

Similarly, we include a dummy variable that accounts for cohabitation periods (cohabitation). If the opportunistic independence theory holds, we will expect cohabitation phases to face higher censorship rates. This theory predicts therefore a positive and significant coefficient associated with cohabitation.

Finally, our set of explanatory variables comprises some control variables that are likely to influence the CC's decisions. We control for the nature of the law at stake (organic, resolution, treaty), the area of the challenged law (economics, electoral, finances, institution, justice and territorial), the year the law was passed (time trend component or time fixed effects), the number of days between the date on which judicial review was requested and the date the decision was made (delay), and we introduce a dummy variable for the 2008 constitutional reform (reform).

We present a series of regressions, which focus on two time periods (1974-2013 and 19952013). The general specification is written as follows:

$$
\operatorname{Pr}\left(\text { Censorship }_{i}\right)=F\left(\beta_{0}+\beta_{1} \mathbb{1}_{\text {Right }_{i}}+\beta_{2} X_{i}+\beta_{3}\left(\mathbb{1}_{\text {Right }_{i}} \times X_{i}\right)+\beta_{4} W_{i}+\beta_{5} Z_{t(i)}\right)
$$

where $\mathrm{F}($.$) is a logistic function, \mathbb{1}_{\text {Right }}$ is a dummy equal to 1 when the challenged law was passed under a right-wing legislature, $X_{i}$ is the vector of political variables, $Z_{t(i)}$ is a vector of time variables, and $W_{i}$ contains the remaining variables.

Variables included in the vector $X_{i}$ change from one specification to another. In all specifications, $X_{i}$ includes pres $R W$. In specifications 1 to $3, X_{i}$ also includes comp $R W$. In specifications 4 to $7, \operatorname{comp} R W$ is replaced by share $R W$. The vector $Z_{t(i)}$ also changes across specifications. In specifications 1 and 4 , it includes a linear time trend. In specifications 2 and $5, Z_{t(i)}$ contains legislature fixed-effects. In specifications 3 and 6 , the vector $Z_{t(i)}$ is made up of both legislature and year fixed-effects. Finally, in specification $7, Z_{t(i)}$ contains legislature, year and court fixed-effects. ${ }^{15}$

The vector of control variables $W_{i}$ includes: a dummy variable for cohabitation (cohab), a dummy variable for the alignment of the Senate (senate), the CC's previous decision (previous), the CC's other decisions made on the same day (sameDay), the number of previous censorships since the beginning of the parliamentary session (parliamentary), the time the $\mathrm{CC}$ took to make the decision (delay), a series of dummy variables for the area of law (economics, electoral, finances, institution, justice and territorial), a series of dummy variables for the nature of the law (organic, resolution and treaty), and a series of dummy variables for the institution which requested judicial review (senators, joint, presR, primeM, presS, and presA). Finally, specifications 4 to 7 include two additional variables for the 1995-2013 time period. Indeed, in order to account for the potential effects of the presence of former

\footnotetext{
${ }^{15}$ Note that we are unable to run specification 7 with the variable $\operatorname{comp} R W$ because the court fixed-effects are collinear with compRW.
} 
Presidents of the Republic, we control for the attendance of both Giscard d'Estaing and Jacques Chirac (giscard and chirac). As we show in the appendix discussing case attendance, their presence may however raise some concerns, which is why we propose to include this in specifications 4 to 7 .

\begin{tabular}{lll}
\hline \hline Theory & Variable & Expected Sign \\
\hline Attitudinal Model & $\mathbb{1}_{\text {Right }} \times \operatorname{compRW}$ & - \\
& $\mathbb{1}_{\text {Right }} \times$ share $R W$ & - \\
& $\mathbb{1}_{\text {Right }} \times$ presRW & - \\
\hline Self-Restraint Theory & previous & - \\
& parliamentary & - \\
& sameDay & - \\
\hline Opportunistic Independence & senate & - \\
& cohabitation & + \\
\hline \hline
\end{tabular}

Table 1: Predictions of the impact on censorship regarding the three theories.

\section{Results}

Table 6 displays the results of seven specifications (described above). Specifications 1 to 3 deal with all cases from 1974 to 2013. Specifications 4 to 7 focus only on cases decided from 1995 to 2013. Under all specifications, we have reported two statistics: the log-likelihood, and the McFadden's pseudo-R square.

Attitudinal Model As far as political/ideological voting is concerned, our results point to serious doubts about Justices' political neutrality.

In order to interpret the impact of the composition of the $\mathrm{CC}$ on the censorship likelihood, we decompose the effect between laws passed under left-wing legislatures and those passed by right-wing majorities. The coefficient associated with the composition of the $\mathrm{CC}$ for left-wing laws is equal to the coefficient of compRW, share $R W$ or pres $R W$ without the coefficient associated with the interaction variable. The coefficient for right-wing laws is the sum of the coefficients associated with the previous variables plus the coefficient associated with the interaction term. ${ }^{16}$ Table 2 summarizes the results.

As far as the proportion of right-wing Justices is concerned, we observe two sets of results. First, when we consider compRW over the full period 1974-2013, we do not detect any impact of the proportion of Justices appointed by right-wing officials on the censorship likelihood, whatever the coalition which passed the challenged law. On the contrary, specifications 4 to 7 all find evidence supporting the attitudinal model: the proportion of Justices who take part in the decision significantly decreases the censorship risks for right-wing laws. This result is robust to the fixed-effects (FE) specifications. Specification $6 \mathrm{n}$ which includes year and legislature $\mathrm{FE}$ but no court $\mathrm{FE}$, also detects a positive impact on left-wing laws: the more

\footnotetext{
${ }^{16}$ See Balli and Sørensen (2013) for the interpretation of interaction variables.
} 
Table 2: Impact of the CC's composition.

\begin{tabular}{|c|c|c|c|c|c|c|c|c|c|}
\hline & & $(1)$ & $(2)$ & (3) & $(4)$ & (5) & (6) & (7) & $(4 \mathrm{e})$ \\
\hline \multirow{2}{*}{$\operatorname{comp} R W$} & Left-wing laws & 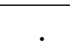 & - & . & & & & & \\
\hline & Right-wing laws & . & . & . & & & & & \\
\hline \multirow{2}{*}{ share $R W$} & Left-wing laws & & & & & & + & . & \\
\hline & Right-wing laws & & & & - & - & - & - & \\
\hline \multirow{2}{*}{ presRW } & Left-wing laws & . & + & . & + & + & - & + & \\
\hline & Right-wing laws & . & + & - & + & + & - & - & \\
\hline
\end{tabular}

Note: We report a plus or minus sign when the p-value is lower than $5 \%$. Otherwise, we report a dot.

Justices appointed by right-wing coalitions attend the decisions for left-wing laws, the more likely these laws are to be censored. This also supports the attitudinal model.

In order to test whether the difference between the two sets of results is driven by the reduced period considered in specifications 1 to 7 or by the gain information that is included in share $R W$ compared to compRW, we run specification 4 by substituting compRW by share $R W$, which yields specification 4e. This new specification does not reject the null hypothesis for compRW unlike specification 4 did with share $R W$ for right-wing laws. This finding indicates that the above results supporting the attitudinal model are not driven by the reduced time period but by the additional information contained in share $R W$ compared to $\operatorname{comp} R W$.

Second, regarding the effect of the fact that the President of the CC was appointed by a right-wing official (presRW), we find mixed results. Some specifications fail at detecting any effect (1 and 4e). Some others detect an increase in the censorship likelihood for both right-wing and left-wing laws (specifications 2, 4 and 5). Specification 6 concludes that the variable pres $R W$ has a negative impact on both types of laws. Only specifications 3 and 7 are aligned with the attitudinal model.

Running a Variance Inflation Factor analysis, we detect one source of collinearity which may affect previous results, i.e. the correlation between share $R W$ and pres $R W$.

First, to investigate whether our results are not driven by collinearity between share $R W$ and pres $R W$, we compute the correlation coefficient, which turns out to be equal to 0.804 (p-value: 0.000). The strong correlation between these two variables can be explained by the fact that the Chief Justice is appointed by the President of the Republic, and that Justices are also more likely to be appointed by right-wing parties when the Chief Justice is himself/herself chosen by a right-wing President of the Republic.

To discriminate between the respective roles of these two variables, we run a series of regressions excluding one of them in turn. Specification 4 a excludes presRW and $\mathbb{1}_{\text {Right }} \times$ pres $R W$, while specification $4 \mathrm{~b}$ excludes share $R W$ and $\mathbb{1}_{\text {Right }} \times$ share $R W$. As one can see, the results of specification 4 associated with share $R W$ remain qualitatively identical, and the magnitude of the coefficients is not affected. Results associated with pres $R W$ substantially change when share $R W$ is dropped: they are now consistent with specification 7 , and support 
the attitudinal model. Indeed, pres $R W$ is associated with significantly more censorship for left-wing laws and with less censorship for right-wing laws.

All in all, these results tend to go in the direction of the attitudinal theory. Separate regressions indicate that both the proportion of Justices appointed by right-wing parties and the party that appointed the Chief Justice reduce the censorship probability for rightwing laws. We are however not able to distinguish between the two effects because of the collinearity of our variables. We do not know therefore whether the right-wing appointed Chief Justice or the other right-wing appointed Justices vote in a political and/or ideological manner. Our estimations however suggest that some political/ideological voting happens.

Judicial Self-Restraint Our estimations seem to confirm the relevance of the judicial self-restraint theory. In fact, we observe that two out of the three variables of interest (previous and parliamentary) have a negative impact on the censorship likelihood (in almost all specifications). These results suggest that Justices are respectively (1) less likely to censor when their last decision was an invalidation, and (2) less likely to censor the more they have censored since the beginning of the parliamentary session. Nevertheless, we do not detect any effect of the number of invalidations given on the same day.

The negative and significant impact associated with parliamentary might however be driven by two other factors in addition to judicial self-restraint. First, it might result from the linear time trend that we impose in specification 4. One can nevertheless remark that this effect is robust to the other specifications which include year fixed-effects instead of a linear time trend. Second, this result might be due to a change in the quality of law within a parliamentary session. In such a case, the variable parliamentary would simply show the decrease in quality over months of the parliamentary session. To investigate this issue, we run specification 4 including a linear trend (the number of months since the beginning of the parliamentary session). The resulting estimation rejects the hypothesis that our results were driven by a change in the quality of law within the parliamentary session. ${ }^{17}$

Altogether, these results support the judicial self-restraint theory, in the sense that Justices are more reluctant to censor the more they have censored in the past. These results seem to confirm Schnapper's theory about the existence of a "censorship quota" (i.e. a maximum number of censorship decisions).

Opportunistic Independence We now turn to the analysis of the two variables related to opportunistic independence: cohabitation and senate.

First, regarding cohabitation, we find that cohabitation periods are associated with more censorship: the coefficient associated with cohabitation is indeed positive and significant in specifications 4 to 7 (1995-2013). It is also weakly significant in specifications 2 and 3 (1974-2013). This result is in alignment with the opportunistic independence theory.

Second, as far as the senate variable is concerned, the picture is more complex. It is indeed associated with a positive impact on the censorship likelihood in almost all specifications of table 6. This result would entail that, when the majority of the National Assembly and the majority of the Senate are aligned, the government faces a higher censorship probability.

\footnotetext{
${ }^{17}$ The coefficient associated with parliamentary remains significant, but the coefficient associated with the linear time of the parliamentary session is not statistically different from zero.
} 
In other words, when both Chambers support the government, the $\mathrm{CC}$ is more likely to invalidate a law. This result would not support the opportunistic independence theory, but could be explained by the fact that the government passes less consensual -and therefore less constitutional- laws when it controls both Chambers.

However, the coefficient of correlation between cohabitation and senate in the 1995-2013 period is highly negative $(-0.898)$ and statistically different from zero ( $\mathrm{p}$-value $=0.000$ ), which raises serious collinearity concerns. Indeed, cohabitation occurred only once in the 1995-2013 period, and the senate was opposed to the National Assembly during this whole period. To test whether our results are driven by the collinearity of our variables, we proceed as follows: first, we run specification 4 by dropping cohabitation (specification 4c), and then by dropping senate (specification $4 \mathrm{~d}$ ). Results of table 7 show that only cohabitation remains significant, which suggests the censorship likelihood is higher under cohabitation, but not necessarily higher when the Senate and the National Assembly are opposed.

Control variables We now turn to a discussion of the control variables. Table 8 in the appendix displays the results of the estimations of specifications 1 to 7 .

A few observations can be made in the light of these elements. First, it appears that treaties have been less likely to be invalidated by the CC than the reference group, i.e. regular statutes. This result is however driven by the collinearity with presRep, whose coefficient is positive and highly significant. This reflects the fact that the President of the Republic asked the $\mathrm{CC}$ to review treaties only. Second, we also observe that resolutions, i.e. bills dealing with the regulation of parliamentary activities, have been more likely to be invalidated in recent years (1995-2013 subsample). Similarly, this second observation results from the high degree of correlation with presAssem and presSenate, whose associated coefficients are both negative and highly significant in specifications 4 to 7 . Third, it appears that laws that have been challenged by both Senators and Deputies are much more likely to be censored. This result is in line with the opportunistic independence theory, since a joint request results in a more isolated government, which may, in fine, give more freedom to the $\mathrm{CC}$ to rule against the government. The positive and statistically significant coefficient associated with joint can also result from a selection effect: laws which are contested by both Senators and Deputies may also very well be less constitutional per se. Lastly, one can note that the area of the challenged law plays little role. Only budget bills face a higher censorship likelihood. ${ }^{18}$

\section{Discussion}

In the preceding analysis, we have found some evidence related to three theories of judicial decision-making: the attitudinal model, the judicial self-restraint theory and the opportunistic independence theory. We also found puzzling elements regarding the attitudinal and the opportunistic independence models.

To sum up our findings, we found that :

\footnotetext{
${ }^{18}$ The high degree of censorship for budget bills is explained by the so-called cavaliers budgétaires, i.e. legislative provisions which are off-topic.
} 
- Justices are influenced by political and/or ideological concerns when ruling on the conformity of laws with the constitution;

- Justices try to limit the number of censorship decisions;

- Justices are in general more likely to rule against the government's interests if the Prime Minister and the President of the Republic are not from the same party (cohabitation).

These results are striking because they give a detailed and broad picture of the determinants of the CC's decisions. They show that elements of the three theories play an important role in determining Justices' choices.

As the econometric investigation has showed, political or ideological components affect Justices. As far as political/ideological voting is concerned, it has been shown in the literature that two effects may be at stake (Miles and Sunstein (2008)). First, this finding may be due to the fact that individual Justices are less likely to strike down laws passed by the party that appointed them. Second, it may also be that this first effect is amplified the more Justices appointed by the same party take part in the decision. ${ }^{19}$ Such panel effects would reinforce the first effect: politicized Justices would be even more politicized when they rule with Justices who share their opinions.

the high level of political and ideological influence for CC's decisions represents a serious issue, especially since Justices do not seem to be aware of it (Schnapper (2010)) ${ }^{20}$ Since most of the appointees have had, at some point, links with political parties, it may be that their political preferences keep influencing their perception. In this respect, the current appointment mechanism may be accountable for the politicization of the CC. Thus, reforms that aim at increasing the level of judicial independence of the $\mathrm{CC}$ by changing the appointment process, or by giving more power to the judiciary, would definitely go in the right direction.

Similarly, our investigations suggest that cohabitation may severely increase the risks of invalidation. This result is in line with the judicial self-restraint theory, and directly questions the independence of the CC. If this finding is effectively driven by the decrease of political pressure exerted on the $\mathrm{CC}$ when the polity is divided, it suggests that the CC suffers severely from political influence when political power is concentrated. However, we cannot rule out the possibility that this result is driven by a change in the quality of the laws passed during cohabitations. Indeed, the French political system is, during cohabitation, much closer to a parliamentary system, where Deputies play a greater role in the law-making process. ${ }^{21}$ The increased role of Deputies may affect the quality of laws, and may, in fine, lead to more censorship decisions. We believe however that this alternative theory is less likely to hold than the opportunistic independence theory, since majoritarian parties should seek to pass

\footnotetext{
${ }^{19}$ This effect was described in Miles and Sunstein (2008). The authors say: "Democratic appointees show especially liberal voting patterns when sitting on all-Democratic panels; Republican appointees show especially conservative voting patterns when sitting on all-Republican panels."

${ }^{20}$ Schnapper argues in fact that Justices do not engage in political or ideological voting since it would damage their credibility inside the CC. More specifically, she writes: "Jean-Claude Colliard noticed that a Justice who would keep voting according to the interests of the party that appointed him/her would lose credibility with his/her colleagues". (In French: "Jean-Claude Colliard fait remarquer qu'un conseiller qui voterait systématiquement en faveur des positions de celui qui l'a nommé se déshonnorerait vis-à-vis de ses collègues.") (p.304) Schnapper (2010).

${ }^{21}$ Under cohabitation, the government cannot rely on the support of the President of the Republic. In order to maximize its support, it generally gives a greater role to Deputies in the law-making process.
} 
more extreme laws when they control both the executive and the legislative branches, which should lead to lower censorship rates during cohabitation.

One of the most innovative contributions of our work lies in the detection of judicial self-restraint. However, motivations for such a behavior are not clear, and it is very likely that Justices are not totally aware of this phenomenon. So far, we see two reasons that may explain Justices' behavior. First, their reluctance to invalidate may be due to their willingness to respect the decisions of a legitimately elected Parliament (while they are only appointed Justices). Second, as Schnapper (2010) claims, it could be due to their fear of a reform of the $\mathrm{CC}$, and therefore to a lack of independence. ${ }^{22}$ It is very likely that, in reality, both reasons influence Justices' choices. Here again, the lack of independence of the CC is very likely to influence Justices' decisions. Nevertheless, we cannot completely exclude the possibility that these findings are driven by a change in the quality of law. The negative influence of the previous decision may simply reflect the fact that the majority exerts more care for future laws when it has faced a recent censorship. Although we are not able to control for the strategic anticipation of the government, we believe that this may only play a limited role: because of the length of the legislative process, the government can hardly anticipate future decisions of the $\mathrm{CC}$ when it drafts the main legal provisions of a new bill. Moreover, regarding the second effect associated with the judicial self-restraint theory, i.e. the decrease of the censorship probability due to the number of previous invalidations in parliamentary session, one could suspect it to be driven by a steady increase in the quality of laws over the parliamentary session. In the above section, we commented on an alternative specification we run to control for this potential issue by including a linear trend in the parliamentary session. We concluded that our results were not driven by a change of quality over the parliamentary session.

Limitations Although these results raise serious questions about the French institutional framework, they must be interpreted with caution mainly because of the limited availability of data.

First, as far as political/ideological voting is concerned, individual votes are not available, which prevents us from investigating individual voting patterns. Moreover, the collinearity concerns raised in the econometric analysis prevents us from distinguishing what is due to regular Justices and what is due to the Chief Justice. So far, we are able to say that something happens in the black box of the CC, but we cannot say what happens. Second, the absence of individual votes prevents us from investigating related concerns, such as panel effects. For instance, Cameron and Kornhauser (2010) have shown that collective judicial decision-making may have specific characteristics different from those commonly held in legislative studies. Repeated interactions between Justices may for instance lead them to negotiate with each other. The authors emphasize indeed that standard models make a separability assumption, which "insures that each judge's decision on a case is independent of her decision on other cases". This assumption is however very likely to be violated in

\footnotetext{
22"Worries about the destiny of the institution -whose legitimacy has never been fully recognized and about which politicians keep debating- force Justices to remain cautious." (In French: "L'inquiétude sur le destin d'une institution dont la légitimité n'est jamais totalement établie, et à propos de laquelle des reformes ont toujours été débattues, contribue à rendre les conseillers prudents.") Schnapper (2010).
} 
case of collective decision-making. Epstein et al. (2011) also show that dissent aversion may decrease Justices' willingness to depart from the group's dominant opinion.

Another possible challenge to the previous analysis lies in possible strategic interactions from the government's side. In fact, if the government were aware of the factors that might influence the CC's decisions, it could try to strategically change its agenda, or to modify the content of its laws. In parallel to this work, we have tried to address this issue. To do so, we have collected data of public inquiries for the Lower Chamber from 1997 to 2012, and we have run several regressions to figure out whether the level of political consensus of laws was affected by the decisions or by the composition of the CC. So far, all our attempts failed at detecting any strategic interaction from the government's side. Still, we believe that such an investigation should be part of a future research project. Let us finally note that any strategic moves from the government's side would only strengthen our results. In fact, if the government were to pass more consensual laws when facing a politically more opposed $\mathrm{CC}$, it would reduce its censorship likelihood. Since we find some evidence for political/ideological voting, it would mean that the actual level of political/ideological voting would be even worse. In this respect, the results we reported above can be seen as a lower bound.

Aside from these two limitations, our empirical strategy faces other limits. First, our analysis is focused on only one dimension of constitutional review. In fact, we have focused on how the CC reports its decision (censorship or conformity), but we have neglected more detailed classifications (e.g. constitutional interpretation by the CC). Second, we have attempted to capture as many components of the reviewed laws as possible. We have controlled indeed for the type of law at stake (treaty, parliamentary rules, organic laws, regular statutes), the delay of the decision, and finance laws, but it may be that these controls were not sufficient to capture core issues which may affect censorship. Finally, it might be that Justices select, at least partially, which cases they attend. We propose in the appendix a discussion to investigate this issue. However, the limited availability of data makes it very difficult to ensure that Justices do not select cases.

\section{Conclusion}

This article has aimed at investigating the relevance of three theories of judicial decisionmaking for the French Constitutional Council: the attitudinal model, the judicial self-restraint theory, and the opportunistic independence theory. To disentangle the role of these three theories, we analyzed rulings of the Constitutional Council from 1974 to 2013, and, more specially, from 1995 to 2013.

We found some evidence supporting the three theories, although we were not able to disentangle the specific roles of the Chief Justice and the regular Justices for the attitudinal model. All in all, we found (1) that Justices are influenced by political/ideological concerns when deciding on the conformity of laws with the constitution, (2) that they are reluctant to invalidate laws voted by the Parliament, and (3) that the Constitutional Council is more independent when the Prime Minister and the President of the Republic are not from the same party.

In the last section, we discussed the implications of our findings. We concluded that our 
results support the three theories on judicial decision-making, which urges for an institutional reform of the Constitutional Council. We underlined indeed that political/ideological voting was likely to occur because of the appointment process. Moreover, we stressed that judicial self-restraint may also be driven by the fear of a reform of the Constitutional Council, and, therefore by the lack of independence. Finally, we noted that the higher risk of censorship under cohabitation is very likely to reflect the pressure on the Constitutional Council that occurs when the President of the Republic and the Prime Minister are from different parties.

The discussion also acknowledged some limits to our approach. First, data availability makes it more difficult in a study of the French Constitutional Council to replicate studies made in other countries. Our results should therefore be interpreted with caution, since some panel effects and related concerns might be at stake. Second, analysis of Supreme Courts' decisions is always made at the political equilibrium. Other theories, such as the strategic model, may account for other strategic interactions that we did not consider here. Our results might be partially driven by unobserved changes in the inherent quality of laws. Third, part of our empirical strategy has relied on the variations in the number of Justices from one decision to another. Our results are therefore highly dependent on the assumption that changes in attendance are purely random, and are not motivated by political, strategic or ideological concerns. Case selection is also discussed in the appendix, we cannot fully ensure that judges do not select which cases they attend.

All in all, we believe that the linkages between the $\mathrm{CC}$ and the central political actors are too strong. In our view, an institutional reform should seek to increase the level of independence of the $\mathrm{CC}$ by changing the appointment process and by giving more power to the judiciary. In this respect, the 2008 constitutional reform, which gave the $\mathrm{CC}$ the power of concrete review, leads to the same policy recommendation: the increase in the complexity of the work of the $\mathrm{CC}$ following from concrete reviews also urges for an increase in the proportion of legal experts sitting at the CC, at the expense of former politicians. 


\section{A Time Components}

Decisions of the $\mathrm{CC}$ can be seen as a time series. In fact, we observe decisions of a unique actor over years, and the usual challenges faced by time series may also apply here. A fundamental limitation, however, consists in the fact that the decisions of the CC are not made on a regular basis (e.g. monthly, yearly), and that several decisions are sometimes published on the same day. To disentangle what is due to potential trend and cyclical components and what is due to the real effects of other explanatory variables, we propose to have a first look at the evolution of the censorship rates over time.

Figure 1 displays the yearly average censorship rate since 1974. In order to distinguish between cyclical components and long-trend components, we use a Hodrick-Prescrott filter. The trend component is presented in figure 2. As we can see, the level of censorship has globally increased over the years. Concerning the yearly cyclical component, figure 3 displays the average censorship rate per year of legislature. No real pattern can be observed from the data.

Moreover, we also propose to investigate whether there exists a monthly trend and/or monthly cycles. To do so, we present the average monthly censorship rate in figure 4 . As we can see, no clear pattern appears from the data. One can note that the relatively high censorship rate in December is due to the budget bills, which always face high risks of censorship.

Altogether, the only time component we are able to detect from the data is the global increase in censorship rate over the years studied.

\section{B Robustness Checks, Autocorrelation, and Regression Diagnosis}

\section{B.1 Robustness Checks}

In order to control whether our results are driven by specific coding procedures or specifications, we have explored alternative solutions. First, as far as the econometric specification is concerned, we have also run probit and linear probability models, and the results were qualitatively identical.

Second, we also proposed an alternative coding for Justice Bazy-Malaurie. In fact, while Justice Bazy-Malaurie was originally appointed by Bernard Accoyer (right-wing), she was reappointed by Claude Bartolone (left-wing) at the beginning of 2013. We have therefore computed two versions of our indicators: one in which Justice Bazy-Malaurie remains a right-wing appointed Justice and one in which she switches to a left-wing appointed Justice after her reappointment. Results were nearly identical, since the correlation coefficient was close to 1 .

\section{B.2 Autocorrelation}

A potential bias could emerge in our estimations if the error terms were correlated over time. Indeed: even if our dataset cannot be seen as a true time series (some days have more than 
one decision), the structure is nevertheless very close. This very special structure allowed us to create variables close to lag values of the dependent variable: previous is the average censorship rate of the last decision day.

Biases could emerge in our estimation if the error terms were correlated over time. To deal with this potential issue, we now consider the data as a time series, in which the decisions' publication order corresponds to the time component. We replace the variable previous by the lag value of the dependent variable (L.censorship). When estimating this new model, we estimate a coefficient associated with L.censorship equal to -0.4465 . This coefficient is statistically different from zero at the $5 \%$ level, and statistically not different from what we found for previous. The coefficients associated with both variables have indeed the same sign, the same significance level, and the same magnitude.

Second, to detect potential serial correlation between our error terms, we compute the residuals of this last model (without clustering). The correlation coefficient between the error term and the lag value of the error term is equal to -0.008 , which suggests no serial correlation. Moreover, graph 6 plots the error terms with the lag values of the error terms. The graph detects no autocorrelation. ${ }^{23}$

Third, in order to run the Breusch-Godfrey test, we run the previous model in a linear form (OLS regression) without clusters. ${ }^{24}$ The probability of rightfully rejecting the null hypothesis of the Breusch-Godfrey test is equal to 0.7129. The test fails therefore at rejecting the no-serial correlation hypothesis, which confirms results presented in the article.

\section{B.3 Logit Diagnosis}

Apart from collinearity, which was addressed in the above discussion, we now present several tests to check the validity of our estimations. As a baseline, we will focus on the specification of column 4 of table 6 (1995-2013 time period with a linear trend). To check the robustness of our specification, we proceed to several tests as mentioned by Peng et al. (2002).

First, we proceed to a link test, which aims at testing whether our model is well specified. It regresses the censorship decisions on the predicted values and the square root of the predicted values. If the predicted values turn out to be significant, this entails that the model is not entirely misspecified. If the square root of the predicted values is highly significant, this implies that the model misses some important independent variables. Running the link test on the logistic regression of column 4 yields a significant coefficient for the predicted values (at the 1\% level), and to a non-significant coefficient for the square value of the predicted values at the $10 \%$ level. This result confirms the quality of our estimation.

Second, we propose to run Hosmer and Lemeshow's goodness-of-fit test. This test aims to measure the match between the predicted probabilities and the binary outcomes. Failing to reject the null hypothesis supports the empirical model. In our case, the probability of rightfully rejecting the null hypothesis is equal to 0.1829 , which validates our estimation.

\footnotetext{
${ }^{23}$ If serial correlation were to be positive, we should observe points in the upper-right and the lower-left parts of the graph. In contrast, if serial correlation were negative, we should observe points in the lower-right and the upper-left parts of the graph.

${ }^{24}$ We cannot use the Durbin-Watson statistics because our set of independent variables includes a lag value of the dependent variable.
} 
Moreover we propose to evaluate the prediction probabilities of our logit estimation, using the ROC curve analysis. The underlying idea of this instrument is to measure the number of false positives and of false negatives that the estimation produces. The explanatory power of the regression to discriminate between censorship and validation decisions is represented by the area under the curve of graph 7 in the appendix. As we can see, the area under the curve is close to 0.8 , which indicates a good quality for the predicted values.

Last but not least, we look at the possibility that a few outliers drive our results. To do so, we plot three statistics associated with each observation: the Pearson residuals (figure 8), the deviance residuals (figure 9), and the Pregibon leverage (figure 10).

As one can see from figure 10, three observations stand out $(352,491,492)$. In order to verify that these outliers do not drive our results, we run our baseline model without these observations. Results were not affected by the drop of these three observations, which supports the previous findings.

\section{Case Selection by Justices}

The issue of case selection has been a major concern in the Law and Economics literature, since cases which ultimately reach courts may not be a representative sample of all conflicts that emerged. Some works have also addressed the issue of case selection by judges themselves, when cases are not randomly assigned within a court (Shayo and Moses (2011)).

In our case, the question of case selection by Justices comes from the fact that Justices do not attend every single case. The variation in the attendance rate of the CC's Justices is useful to estimate the intensity of political/ideological voting. However, if Justices were to select which cases they will attend, and to miss cases they are willing to avoid, our estimations related to share $R W$ would be underestimated.

To investigate case selection by Justices, we present Justices' attendance rates at the CC decisions in table $9 .^{25}$ The first column displays the average attendance rate for each judge. In the second and third columns, we show attendance rates respectively for conformity and censorship decisions. The last column presents the p-values of the two-group meancomparison tests (for conformity and censorship decisions).

First of all, we can remark that, except for the two former Presidents of the Republic, attendance rates are above $90 \%$ for all Justices. Among the 30 regular Justices with rates above $90 \%, 25$ attended more than $95 \%$ of the cases. This suggests that, if case selection occurs, it is very limited in its frequency.

Looking at the fourth column, one can notice that no Justice is actually below the $5 \%$ threshold, which would suggest case selection. It seems that Justices do not attend more regularly censorship decisions than conformity decisions. A potential concern could emerge from Justice Veil, who is very close to the threshold. In fact, she attended all censorship

\footnotetext{
${ }^{25}$ Although comparing the censorship likelihood of attended and unattended cases is not the best way to ensure that case selection does not occur, it is however the most appropriate way given the availability of data.
} 
decisions but only $95.8 \%$ of the conformity decisions.

To further investigate potential case selection, table 10 displays censorship rates when Justices attended the cases. The first three columns show censorship probabilities for decisions attended by Justices per category of law: (1) all laws, (2) laws voted by right-wing coalitions, and (3) laws voted by left-wing coalitions. The last column presents the p-values associated with the two-group mean-comparison tests for the level of censorship of cases attended for the two subsamples (laws voted by right-wing and by left-wing majorities).

As one can note, no regular Justice is below the $5 \%$ threshold in the last column. The former President of the Republic Giscard d'Estaing has a p-value below the threshold. This implies that Giscard d'Estaing attended more censorship decisions under right-wing legislatures than under left-wing legislatures.

Two regular Justices are very close to the $5 \%$ threshold, namely Justice Ameller and Justice Pelletier. As far as Justice Ameller is concerned, one can observe from table 9 that he attended all cases, which implies that this difference in censorship is not due to case selection. Second, Justice Pelletier attended all cases but one, which also shows that she did not select cases she attended.

Remark Regarding the data available to this date, it seems that appointed Justices do not select cases they attend. 


\section{Figures and Tables}

\begin{tabular}{lllll}
\hline \hline Legislature & Color & \multicolumn{2}{c}{$\begin{array}{c}\text { Cohabitation Number of } \\
\text { decisions }\end{array}$} & $\begin{array}{l}\text { Censorship } \\
\text { rate }\end{array}$ \\
\hline $1974-1978$ & Right-wing & No & 35 & .200 \\
$1978-1981$ & Right-wing & No & 36 & .278 \\
$1981-1986$ & Left-wing & No & 77 & .442 \\
$1986-1988$ & Right-wing & Yes & 37 & .432 \\
$1988-1993$ & Left-wing & No & 75 & .400 \\
$1993-1997$ & Right-wing & Partly & 70 & .429 \\
$1997-2002$ & Left-wing & Yes & 68 & .588 \\
$2002-2007$ & Right-wing & No & 93 & .495 \\
$2007-2012$ & Right-wing & No & 98 & .571 \\
$2012-2013$ & Left-wing & No & 23 & .391 \\
\hline & & Total & 612 & .454 \\
\hline
\end{tabular}

Table 3: Number of censorships and censorship rates by legislature. 


\begin{tabular}{|c|c|c|}
\hline Nature of Information & Variable Name & Description \\
\hline \multirow[t]{17}{*}{ Information about the decision } & censorship & Dummy variable equal to one if the $\mathrm{CC}$ invalidated the law. \\
\hline & compRW & Proportion of Justices appointed by right-wing parties. \\
\hline & presRW & Dummy variable equal to one if the President of the $\mathrm{CC}$ was appointed by a right-wing party. \\
\hline & senate & Dummy variable equal to one if the majorities of the Senate and the National Assembly are aligned. \\
\hline & cohabitation & $\begin{array}{l}\text { Dummy variable equal to one in case of cohabitation, i.e. when the Prime Minister and the President } \\
\text { of the Republic are not from the same party. }\end{array}$ \\
\hline & previous & $\begin{array}{l}\text { Dummy variable equal to one if the previous decision was a censorship. If several decisions were made } \\
\text { on the same day, the variable is equal to the share of censorship decisions. }\end{array}$ \\
\hline & parliamentary & Number of previous censorship decisions made since the beginning of the parliamentary session. \\
\hline & sameDay & Number of (other) censorship decisions made the same day. \\
\hline & delay & Number of days between the request for judicial review and the decision. \\
\hline & deputies & $\begin{array}{l}\text { Dummy variable equal to one when the judicial review was requested by } 60 \text { deputies and by } 60 \\
\text { deputies only (reference group). }\end{array}$ \\
\hline & senators & Dummy variable equal to one if judicial review was requested by 60 senators and by 60 senators only. \\
\hline & joint & Dummy variable equal to one if judicial review was requested by both 60 deputies and 60 senators. \\
\hline & presRep & Dummy variable equal to one if judicial review was requested by the President of the Republic. \\
\hline & primeMin & Dummy variable equal to one if judicial review was requested by the Prime Minister. \\
\hline & presSenate & Dummy variable equal to one if judicial review was requested by the President of the Senate. \\
\hline & presAssem & $\begin{array}{l}\text { Dummy variable equal to one if judicial review was requested by the President of the National } \\
\text { Assembly. }\end{array}$ \\
\hline & reform & Dummy variable equal to one if the decision was made after the 2008 constitutional reform. \\
\hline \multirow[t]{11}{*}{ Information about the law } & $\mathbb{1}_{\text {Right }}$ & Dummy variable equal to one if the law was passed under a right-wing legislature. \\
\hline & economics & Dummy variable equal to one if the law implements economic reforms. \\
\hline & electoral & Dummy variable equal to one if the law contains electoral provisions. \\
\hline & finances & Dummy variable equal to one if the law is a budget bill. \\
\hline & institution & Dummy variable equal to one if the law modifies the institutions. \\
\hline & justice & Dummy variable equal to one if the law is about the judiciary system. \\
\hline & territorial & Dummy variable equal to one if the law targets local administrative entities. \\
\hline & regular & Dummy variable equal to one if the law is a regular bill (reference group). \\
\hline & organic & Dummy variable equal to one if the law is an organic bill. \\
\hline & resolution & Dummy variable equal to one if the law is a resolution. \\
\hline & treaty & Dummy variable equal to one if the law is a treaty. \\
\hline \multirow[t]{3}{*}{ Variables for 1995-2013 only } & share $R W$ & Proportion of Justices appointed by a right-wing party among those who attend the decision. \\
\hline & giscard & Dummy variable equal to one if former President Giscard d'Estaing attended the decision. \\
\hline & chirac & Dummy variable equal to one if former President Chirac attended the decision. \\
\hline
\end{tabular}

Table 4: List of variables. 


\begin{tabular}{|c|c|c|c|c|c|c|c|c|c|c|}
\hline \multirow[b]{3}{*}{ Variable } & \multicolumn{6}{|c|}{ 1974-2013 } & \multicolumn{4}{|c|}{$1995-2013$} \\
\hline & \multicolumn{2}{|c|}{ All Laws } & \multicolumn{2}{|c|}{ Right Laws } & \multicolumn{2}{|c|}{ Left Laws } & \multicolumn{2}{|c|}{ Right Laws } & \multicolumn{2}{|c|}{ Left Laws } \\
\hline & Mean & $\begin{array}{l}\text { Stand. } \\
\text { Dev. }\end{array}$ & Mean & $\begin{array}{l}\text { Stand. } \\
\text { Dev. }\end{array}$ & Mean & $\begin{array}{l}\text { Stand. } \\
\text { Dev. }\end{array}$ & Mean & $\begin{array}{l}\text { Stand. } \\
\text { Dev. }\end{array}$ & Mean & $\begin{array}{l}\text { Stand. } \\
\text { Dev. }\end{array}$ \\
\hline censorship & .454 & .498 & .447 & .498 & .465 & .5 & .514 & .501 & .538 & .501 \\
\hline $\mathbb{1}_{\text {Right }}$ & .603 & .49 & 1 & 0 & 0 & 0 & 1 & 0 & 0 & 0 \\
\hline compRW & .719 & .227 & .77 & .23 & .642 & .2 & .814 & .16 & .675 & .18 \\
\hline presRW & .562 & .497 & .71 & .454 & .337 & .474 & .884 & .321 & .604 & .492 \\
\hline cohabitation & .245 & .43 & .222 & .416 & .28 & .45 & 0 & 0 & .747 & .437 \\
\hline senate & .621 & .486 & .967 & .178 & .095 & .293 & .944 & .23 & .253 & .437 \\
\hline sameDay & .301 & .519 & .301 & .525 & .3 & .511 & .282 & .509 & .242 & .431 \\
\hline previous & .452 & .453 & .436 & .454 & .477 & .451 & .489 & .457 & .559 & .459 \\
\hline parliamentary & 3.768 & 2.961 & 3.913 & 3.302 & 3.547 & 2.339 & 4.912 & 3.486 & 3.857 & 2.593 \\
\hline delay & 17.913 & 8.298 & 17.214 & 8.271 & 18.979 & 8.242 & 14.921 & 7.638 & 18.2 & 8.122 \\
\hline finances & .116 & .321 & .106 & .308 & .132 & .339 & .093 & .291 & .165 & .373 \\
\hline organic & .18 & .384 & .209 & .407 & .136 & .343 & .199 & .4 & .187 & .392 \\
\hline resolution & .087 & .281 & .081 & .274 & .095 & .293 & .083 & .277 & .055 & .229 \\
\hline treaty & .02 & .139 & .014 & .116 & .029 & .168 & .019 & .135 & .044 & .206 \\
\hline senators & .124 & .33 & .095 & .293 & .169 & .375 & .074 & .262 & .154 & .363 \\
\hline joint & .276 & .447 & .263 & .441 & .296 & .458 & .329 & .471 & .341 & .477 \\
\hline presRep & .016 & .127 & .011 & .104 & .025 & .156 & .014 & .117 & .044 & .206 \\
\hline primeMin & .201 & .401 & .233 & .423 & .152 & .36 & .208 & .407 & .198 & .401 \\
\hline presSenate & .044 & .206 & .043 & .204 & .045 & .208 & .042 & .2 & .011 & .105 \\
\hline presAssem & .046 & .209 & .043 & .204 & .049 & .217 & .046 & .211 & .044 & .206 \\
\hline year & 1995.4 & 10.996 & 1997.1 & 11.863 & 1992.8 & 8.953 & 2005.8 & 4.574 & 2002.7 & 5.778 \\
\hline economics & .142 & .349 & .132 & .339 & .156 & .364 & .165 & .372 & .143 & .352 \\
\hline electoral & .094 & .293 & .1 & .3 & .086 & .282 & .069 & .254 & .11 & .314 \\
\hline finances & .124 & .33 & .108 & .311 & .148 & .356 & .101 & .302 & .165 & .373 \\
\hline institution & .078 & .269 & .089 & .285 & .062 & .241 & .101 & .302 & .066 & .25 \\
\hline justice & .055 & .229 & .067 & .251 & .037 & .189 & .046 & .21 & .033 & .18 \\
\hline resolution & .086 & .281 & .081 & .273 & .095 & .293 & .083 & .276 & .055 & .229 \\
\hline territorial & .062 & .241 & .051 & .221 & .078 & .269 & .05 & .219 & .055 & .229 \\
\hline shareRW & & & & & & & .821 & .175 & .706 & .155 \\
\hline giscard & & & & & & & .347 & .477 & .165 & .373 \\
\hline chirac & & & & & & & .144 & .351 & .011 & .105 \\
\hline
\end{tabular}

Table 5: Summary Statistics. 
Table 6: Logit Estimation of the Censorship Decision.

\begin{tabular}{|c|c|c|c|c|c|c|c|}
\hline $\begin{array}{l}\text { Specification } \\
\text { Period }\end{array}$ & $\begin{array}{c}(1) \\
1974 \\
-2013\end{array}$ & $\begin{array}{c}(2) \\
1974 \\
-2013\end{array}$ & $\begin{array}{c}(3) \\
1974 \\
-2013\end{array}$ & $\begin{array}{c}(4) \\
1995 \\
-2013\end{array}$ & $\begin{array}{c}(5) \\
1995 \\
-2013\end{array}$ & $\begin{array}{c}(6) \\
1995 \\
-2013\end{array}$ & $\begin{array}{c}(7) \\
1995 \\
-2013\end{array}$ \\
\hline compRW & $\begin{array}{l}0.0815 \\
(1.155)\end{array}$ & $\begin{array}{c}-1.680^{*} \\
(0.926)\end{array}$ & $\begin{array}{c}4.035 \\
(4.618)\end{array}$ & & & & \\
\hline $\mathbb{1}_{\text {Right }} \times \operatorname{compRW}$ & $\begin{array}{c}0.129 \\
(0.958)\end{array}$ & $\begin{array}{c}1.906 \\
(1.629)\end{array}$ & $\begin{array}{c}5.307 \\
(9.283)\end{array}$ & & & & \\
\hline share $R W$ & & & & $\begin{array}{c}0.377 \\
(0.972)\end{array}$ & $\begin{array}{c}1.283 \\
(1.615)\end{array}$ & $\begin{array}{l}7.883^{* *} \\
(3.582)\end{array}$ & $\begin{array}{c}-6.235^{*} \\
(3.496)\end{array}$ \\
\hline $\mathbb{1}_{\text {Right }} \times$ share $R W$ & & & & $\begin{array}{c}-9.543^{* * *} \\
(2.267)\end{array}$ & $\begin{array}{c}-12.87^{* * *} \\
(3.180)\end{array}$ & $\begin{array}{c}-17.40^{* * *} \\
(3.519)\end{array}$ & $\begin{array}{l}-5.996 \\
(4.694)\end{array}$ \\
\hline pres $R W$ & $\begin{array}{c}-0.00865 \\
(0.535)\end{array}$ & $\begin{array}{c}0.809 * * * \\
(0.310)\end{array}$ & $\begin{array}{l}-0.559 \\
(1.510)\end{array}$ & $\begin{array}{c}0.462^{* *} \\
(0.201)\end{array}$ & $\begin{array}{c}0.893^{* * *} \\
(0.215)\end{array}$ & $\begin{array}{c}-13.02^{* * *} \\
(1.133)\end{array}$ & $\begin{array}{c}4.576^{* * *} \\
(0.567)\end{array}$ \\
\hline $\mathbb{1}_{\text {Right }} \times$ presRW & $\begin{array}{c}0.197 \\
(0.765)\end{array}$ & $\begin{array}{c}0.532 \\
(0.437)\end{array}$ & $\begin{array}{c}-17.07^{* * *} \\
(4.086)\end{array}$ & $\begin{array}{l}1.452^{* *} \\
(0.624)\end{array}$ & $\begin{array}{c}6.113^{* * *} \\
(1.146)\end{array}$ & $\begin{array}{c}-8.970^{* * *} \\
(0.738)\end{array}$ & $\begin{array}{c}-10.86^{* * *} \\
(1.193)\end{array}$ \\
\hline cohab & $\begin{array}{c}0.347 \\
(0.224)\end{array}$ & $\begin{array}{c}0.400^{*} \\
(0.210)\end{array}$ & $\begin{array}{c}1.922^{*} \\
(1.018)\end{array}$ & $\begin{array}{c}6.812^{* * *} \\
(0.823)\end{array}$ & $\begin{array}{c}2.867^{* * *} \\
(0.274)\end{array}$ & $\begin{array}{c}21.70^{* * *} \\
(1.862)\end{array}$ & $\begin{array}{c}18.61^{* * *} \\
(1.535)\end{array}$ \\
\hline senate & $\begin{array}{l}-0.665 \\
(0.700)\end{array}$ & $\begin{array}{c}0.943^{* * *} \\
(0.238)\end{array}$ & $\begin{array}{c}1.645^{* * * *} \\
(0.626)\end{array}$ & $\begin{array}{c}1.697^{* * *} \\
(0.304)\end{array}$ & $\begin{array}{c}1.249^{* * *} \\
(0.227)\end{array}$ & $\begin{array}{c}1.811^{* * *} \\
(0.362)\end{array}$ & $\begin{array}{l}1.323^{* *} \\
(0.522)\end{array}$ \\
\hline sameDay & $\begin{array}{l}-0.135 \\
(0.153)\end{array}$ & $\begin{array}{l}-0.132 \\
(0.161)\end{array}$ & $\begin{array}{c}-0.318^{*} \\
(0.192)\end{array}$ & $\begin{array}{c}-0.267 \\
(0.229)\end{array}$ & $\begin{array}{c}-0.301 \\
(0.209)\end{array}$ & $\begin{array}{l}-0.523 \\
(0.325)\end{array}$ & $\begin{array}{c}-0.512^{*} \\
(0.294)\end{array}$ \\
\hline previous & $\begin{array}{l}-0.199^{*} \\
(0.119)\end{array}$ & $\begin{array}{c}-0.276^{* *} \\
(0.137)\end{array}$ & $\begin{array}{c}-0.711^{* * *} \\
(0.133)\end{array}$ & $\begin{array}{c}-0.263^{* *} \\
(0.117)\end{array}$ & $\begin{array}{c}-0.263^{*} \\
(0.156)\end{array}$ & $\begin{array}{c}-0.632^{* * *} \\
(0.0915)\end{array}$ & $\begin{array}{c}-0.832^{* * *} \\
(0.132)\end{array}$ \\
\hline parliamentary & $\begin{array}{l}-0.0557 \\
(0.0460)\end{array}$ & $\begin{array}{c}-0.0894^{*} \\
(0.0484)\end{array}$ & $\begin{array}{c}-0.135^{* *} \\
(0.0585)\end{array}$ & $\begin{array}{c}-0.0985 * * * \\
(0.0209)\end{array}$ & $\begin{array}{c}-0.0805^{* * *} \\
(0.0127)\end{array}$ & $\begin{array}{c}-0.149 * * * \\
(0.0316)\end{array}$ & $\begin{array}{r}-0.127 * * * \\
(0.0435)\end{array}$ \\
\hline Linear Trend & Yes & No & No & Yes & No & No & No \\
\hline Year FE & No & Yes & Yes & No & Yes & Yes & Yes \\
\hline Legislature FE & No & No & Yes & No & No & Yes & Yes \\
\hline Court FE & No & No & No & No & No & No & Yes \\
\hline Observations & 611 & 611 & 611 & 306 & 306 & 306 & 297 \\
\hline Log-likelihood & -353.21 & -348.64 & -322.17 & -166.40 & -166.52 & -152.55 & -144.23 \\
\hline Pseudo-R ${ }^{2}$ & 0.1611 & 0.1719 & 0.2348 & 0.2143 & 0.2137 & 0.2797 & 0.2977 \\
\hline
\end{tabular}

Note: All specifications include information about the nature of the challenged law (organic, treaty, and resolution), about the content of the law (economics, electoral, finances, institution, justice and territorial), and about the time between when the review was requested and the decision of the CC (delay). Specifications 1 and 4 also include a dummy variable for the 2008 reform (reform).

Clustered standard errors in parentheses.

Significance level: ${ }^{* *}$ significant at $1 \%$ level; ${ }^{* *}$ significant at $5 \%$ level; ${ }^{*}$ significant at $10 \%$ level. 
Table 7: Logit Estimation of the Censorship Decision: Robustness Checks

\begin{tabular}{|c|c|c|c|c|c|}
\hline $\begin{array}{l}\text { Specification } \\
\text { Period }\end{array}$ & $\begin{array}{c}(4 a) \\
1995 \\
-2013\end{array}$ & $\begin{array}{c}(4 b) \\
1995 \\
-2013\end{array}$ & $\begin{array}{c}(4 c) \\
1995 \\
-2013\end{array}$ & $\begin{array}{c}(4 d) \\
1995 \\
-2013\end{array}$ & $\begin{array}{c}(4 \mathrm{e}) \\
1995 \\
-2013\end{array}$ \\
\hline compRW & & & & & $\begin{array}{l}0.6233 \\
(1.563)\end{array}$ \\
\hline $\mathbb{1}_{\text {Right }} \times \operatorname{compRW}$ & & & & & $\begin{array}{c}-2.72 \\
(2.864)\end{array}$ \\
\hline share $R W$ & $\begin{array}{c}1.259 \\
(0.972)\end{array}$ & & $\begin{array}{c}1.663 \\
(1.473)\end{array}$ & $\begin{array}{c}0.860 \\
(0.861)\end{array}$ & \\
\hline $\mathbb{1}_{\text {Right }} \times$ share $R W$ & $\begin{array}{c}-7.462^{* * *} \\
(1.657)\end{array}$ & & $\begin{array}{c}-6.329 * * * \\
(1.986)\end{array}$ & $\begin{array}{c}-9.256^{* * *} \\
(2.133)\end{array}$ & \\
\hline pres $R W$ & & $\begin{array}{c}0.686^{* *} \\
(0.300)\end{array}$ & $\begin{array}{c}0.441 \\
(0.471)\end{array}$ & $\begin{array}{c}0.504^{* *} \\
(0.251)\end{array}$ & $\begin{array}{c}.4701 \\
(0.400)\end{array}$ \\
\hline $\mathbb{1}_{\text {Right }} \times$ pres $R W$ & & $\begin{array}{c}-1.482^{* *} \\
(0.742)\end{array}$ & $\begin{array}{c}2.626^{* *} \\
(1.135)\end{array}$ & $\begin{array}{l}1.802^{* *} \\
(0.752)\end{array}$ & $\begin{array}{c}-.829 \\
(0.515)\end{array}$ \\
\hline cohab & $\begin{array}{c}7.173^{* * * *} \\
(0.749)\end{array}$ & $\begin{array}{c}5.428^{* * * *} \\
(0.979)\end{array}$ & & $\begin{array}{c}4.070 * * * \\
(0.661)\end{array}$ & $\begin{array}{c}6.040^{* * *} \\
(1.349)\end{array}$ \\
\hline senate & $\begin{array}{c}1.817^{* * * *} \\
(0.225)\end{array}$ & $\begin{array}{c}1.476^{* * * *} \\
(0.389)\end{array}$ & $\begin{array}{l}-0.787 \\
(0.745)\end{array}$ & & $\begin{array}{c}1.421^{* * *} \\
(0.290)\end{array}$ \\
\hline sameDay & $\begin{array}{l}-0.242 \\
(0.223)\end{array}$ & $\begin{array}{l}-0.182 \\
(0.191)\end{array}$ & $\begin{array}{l}-0.260 \\
(0.188)\end{array}$ & $\begin{array}{l}-0.270 \\
(0.221)\end{array}$ & $\begin{array}{l}-0.191 \\
(0.192)\end{array}$ \\
\hline previous & $\begin{array}{c}-0.222^{*} \\
(0.114)\end{array}$ & $\begin{array}{c}-0.232^{* *} \\
(0.0988)\end{array}$ & $\begin{array}{l}-0.125 \\
(0.152)\end{array}$ & $\begin{array}{c}-0.238^{*} \\
(0.124)\end{array}$ & $\begin{array}{c}-0.228^{* *} \\
(.1101)\end{array}$ \\
\hline parliamentary & $\begin{array}{c}-0.101^{* * *} \\
(0.0198)\end{array}$ & $\begin{array}{c}-0.101^{* * *} \\
(0.0286)\end{array}$ & $\begin{array}{l}-0.0238 \\
(0.0234)\end{array}$ & $\begin{array}{c}-0.0618^{* *} \\
(0.0298)\end{array}$ & $\begin{array}{c}-0.100 * * * \\
(0.0273)\end{array}$ \\
\hline Linear Trend & Yes & Yes & Yes & Yes & Yes \\
\hline Year FE & No & No & No & No & No \\
\hline Legislature FE & No & No & No & No & No \\
\hline Court FE & No & No & No & No & No \\
\hline Observations & 306 & 306 & 306 & 306 & 306 \\
\hline Log-likelihood & -167.12 & -169.15 & -172.93 & -168.18 & -169.04 \\
\hline Pseudo-R ${ }^{2}$ & 0.2109 & 0.2013 & 0.1835 & 0.2059 & 0.2018 \\
\hline
\end{tabular}

Note: All specifications include information about the nature of the challenged law (organic, treaty, and resolution), about the content of the law (economics, electoral, finances, institution, justice and territorial), and about the time between when the review was requested and the decision of the CC (delay).

Clustered standard errors in parentheses.

Significance level: ${ }^{* * *}$ significant at $1 \%$ level; ${ }^{* *}$ significant at $5 \%$ level; ${ }^{*}$ significant at $10 \%$ level. 
Table 8: Control variables of Table 6 .

\begin{tabular}{|c|c|c|c|c|c|c|c|}
\hline Specification & (1) & $(2)$ & (3) & (4) & $(5)$ & (6) & (7) \\
\hline \multirow[t]{2}{*}{ organic } & -0.879 & -1.023 & -0.834 & -0.139 & -0.257 & -0.721 & -0.305 \\
\hline & $(0.695)$ & $(0.663)$ & $(0.681)$ & $(1.192)$ & $(1.205)$ & $(1.343)$ & $(1.235)$ \\
\hline \multirow[t]{2}{*}{ resolution } & -0.976 & -0.756 & -0.847 & $16.11^{* * *}$ & $16.18^{* * *}$ & $17.08 * * *$ & $19.67^{* * *}$ \\
\hline & $(2.343)$ & $(2.953)$ & $(2.739)$ & $(1.450)$ & $(1.577)$ & $(1.415)$ & $(1.408)$ \\
\hline \multirow[t]{2}{*}{ treaty } & $-13.99 * * *$ & $-13.84^{* * *}$ & $-16.10 * * *$ & $-14.82^{* * *}$ & $-14.46^{* * *}$ & $-16.90 * * *$ & $-18.25 * * *$ \\
\hline & $(0.880)$ & $(0.848)$ & $(1.000)$ & $(1.227)$ & $(1.213)$ & $(1.333)$ & $(1.504)$ \\
\hline \multirow[t]{2}{*}{ senators } & -0.225 & -0.226 & -0.313 & $-0.818^{* * *}$ & $-0.698 * * *$ & $-0.750 * * *$ & $-0.832^{* * *}$ \\
\hline & $(0.201)$ & $(0.230)$ & $(0.243)$ & $(0.178)$ & $(0.233)$ & $(0.244)$ & $(0.321)$ \\
\hline \multirow[t]{2}{*}{ joint } & $0.901^{* * *}$ & $0.902^{* * *}$ & $0.958 * * *$ & $0.836^{* * *}$ & $0.852^{* * *}$ & $0.962^{* * *}$ & $0.820 * * *$ \\
\hline & $(0.193)$ & $(0.198)$ & $(0.276)$ & $(0.233)$ & $(0.227)$ & $(0.300)$ & $(0.288)$ \\
\hline \multirow[t]{2}{*}{ presRep } & $14.70^{* * *}$ & $14.65^{* * *}$ & $17.14^{* * *}$ & $16.88^{* * *}$ & $16.36^{* * *}$ & $19.62^{* * *}$ & $20.55^{* * *}$ \\
\hline & $(1.305)$ & $(1.244)$ & $(1.458)$ & $(1.645)$ & $(1.772)$ & $(1.707)$ & $(1.855)$ \\
\hline \multirow[t]{2}{*}{ primeMin } & -0.0663 & 0.0769 & 0.0354 & -1.205 & -0.978 & -0.328 & -0.793 \\
\hline & $(0.747)$ & $(0.728)$ & $(0.725)$ & $(1.110)$ & $(1.122)$ & $(1.227)$ & $(1.097)$ \\
\hline \multirow[t]{2}{*}{ presSenate } & 0.153 & -0.112 & -0.126 & $-18.09 * * *$ & $-18.25^{* * *}$ & $-19.18^{* * *}$ & $-21.97 * * *$ \\
\hline & $(2.638)$ & $(3.269)$ & $(3.091)$ & $(0.955)$ & $(1.154)$ & $(1.013)$ & $(0.792)$ \\
\hline \multirow[t]{2}{*}{ presAssem } & -0.303 & -0.525 & -0.601 & $-16.29 * * *$ & $-16.38^{* * *}$ & $-17.66^{* * *}$ & $-20.28 * * *$ \\
\hline & $(2.212)$ & $(2.834)$ & $(2.630)$ & $(1.256)$ & $(1.374)$ & $(1.340)$ & $(1.470)$ \\
\hline \multirow[t]{2}{*}{ economics } & -0.332 & $-0.407^{* *}$ & -0.285 & 0.0160 & -0.0548 & 0.0483 & -0.0751 \\
\hline & $(0.207)$ & $(0.203)$ & $(0.217)$ & $(0.298)$ & $(0.300)$ & $(0.279)$ & $(0.268)$ \\
\hline \multirow[t]{2}{*}{ electoral } & $-0.564^{*}$ & $-0.635^{*}$ & -0.613 & -0.196 & -0.183 & -0.0223 & 0.0470 \\
\hline & $(0.327)$ & $(0.335)$ & $(0.391)$ & $(0.572)$ & $(0.565)$ & $(0.618)$ & $(0.540)$ \\
\hline \multirow[t]{2}{*}{ finances } & $1.452^{* * *}$ & $1.393^{* * *}$ & $1.631^{* * *}$ & $1.951^{* * *}$ & $1.859^{* * *}$ & $2.215^{* * *}$ & $2.105^{* * *}$ \\
\hline & $(0.182)$ & $(0.193)$ & $(0.180)$ & $(0.446)$ & $(0.474)$ & $(0.405)$ & $(0.449)$ \\
\hline \multirow[t]{2}{*}{ institution } & -0.00658 & -0.136 & -0.415 & 0.623 & 0.482 & 0.253 & 0.137 \\
\hline & $(0.326)$ & $(0.311)$ & $(0.352)$ & $(0.512)$ & $(0.519)$ & $(0.488)$ & $(0.506)$ \\
\hline \multirow[t]{2}{*}{ justice } & 0.399 & 0.443 & 0.389 & 1.083 & 1.164 & 1.046 & 0.839 \\
\hline & $(0.536)$ & $(0.514)$ & $(0.529)$ & $(0.957)$ & $(0.967)$ & $(0.794)$ & $(0.985)$ \\
\hline \multirow[t]{2}{*}{ territorial } & 0.384 & 0.295 & 0.387 & 1.256 & 1.191 & 1.607 & $1.518^{* *}$ \\
\hline & $(0.413)$ & $(0.439)$ & $(0.489)$ & $(0.862)$ & $(0.891)$ & $(0.995)$ & $(0.758)$ \\
\hline
\end{tabular}

Note: Standard errors in parentheses, clustered by legislature.

Significance level: ${ }^{* * *}$ significant at $1 \%$ level; ${ }^{* *}$ significant at $5 \%$ level; ${ }^{*}$ significant at $10 \%$ level. 
Table 9: Attendance rates per Justice (1995-2013).

\begin{tabular}{|c|c|c|c|c|}
\hline & $\begin{array}{c}(1) \\
\text { All decisions }\end{array}$ & $\begin{array}{c}(2) \\
\text { Conformity }\end{array}$ & $\begin{array}{c}(3) \\
\text { Censorship }\end{array}$ & $\begin{array}{c}(4) \\
\text { P-value }\end{array}$ \\
\hline Abadie & .962 & .925 & 1 & .087 \\
\hline Ameller & 1 & 1 & 1 & . \\
\hline Barrot & .986 & 1 & .971 & .321 \\
\hline Bazy & .984 & .967 & 1 & .306 \\
\hline Belloubet & 1 & 1 & 1 & . \\
\hline Cabannes & 1 & 1 & 1 & . \\
\hline Canivet & .934 & .929 & .938 & .829 \\
\hline Charasse & .957 & 1 & .914 & .083 \\
\hline Chirac & .508 & .519 & .5 & .887 \\
\hline Colliard & .981 & .972 & .988 & .474 \\
\hline Dailly & 1 & 1 & 1 & . \\
\hline Denoix de Saint Marc & .992 & .982 & 1 & .283 \\
\hline Debre & .992 & .982 & 1 & .283 \\
\hline Dumas & .933 & .92 & .95 & .697 \\
\hline Dutheillet & .987 & .972 & 1 & .121 \\
\hline Faure & .935 & .95 & .909 & .67 \\
\hline Giscard d'Estaing & .508 & .439 & .568 & .087 \\
\hline Guena & .99 & .98 & 1 & .292 \\
\hline Guillenchmidt & .947 & .949 & .946 & .943 \\
\hline Haenel & .957 & .943 & .971 & .562 \\
\hline Joxe & .904 & .861 & .941 & .09 \\
\hline Lancelot & .97 & .97 & .971 & .983 \\
\hline Lenoir & .987 & .975 & 1 & .333 \\
\hline Maestracci & 1 & 1 & 1 & . \\
\hline Mazeaud & .981 & .972 & .988 & .474 \\
\hline Pelletier & .985 & .967 & 1 & .277 \\
\hline Pezant & .956 & .941 & .968 & .487 \\
\hline Robert & 1 & 1 & 1 & . \\
\hline Rudloff & 1 & 1 & 1 & . \\
\hline Schnapper & .956 & .972 & .942 & .359 \\
\hline Steinmetz & .988 & .987 & .989 & .894 \\
\hline Veil & .981 & .958 & 1 & .059 \\
\hline
\end{tabular}

Note: To avoid low attendance rates due to illness leading to resignation, we assume mandates begin on the first day that Justices sit and end on the last day they sit. 
Table 10: Censorship rates for decisions attended by Justices.

\begin{tabular}{|c|c|c|c|c|}
\hline & $\begin{array}{c}(1) \\
\text { All laws }\end{array}$ & $\begin{array}{c}(2) \\
\text { Right Laws }\end{array}$ & $\begin{array}{c}(3) \\
\text { Left Laws }\end{array}$ & $\begin{array}{c}(4) \\
\text { P-value }\end{array}$ \\
\hline Abadie & .507 & .391 & .558 & .189 \\
\hline Ameller & .5 & .407 & .582 & .05 \\
\hline Barrot & 493 & .532 & .409 & .349 \\
\hline Bazy & .525 & .59 & .409 & 181 \\
\hline Belloubet & .333 & & .333 & . \\
\hline Cabannes & .355 & .36 & .333 & .906 \\
\hline Canivet & .54 & .564 & .421 & .259 \\
\hline Charasse & .485 & .533 & .381 & 255 \\
\hline Chirac & .563 & .563 & & . \\
\hline Colliard & .543 & .5 & .607 & .2 \\
\hline Dailly & .385 & .385 & & 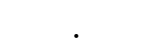 \\
\hline Debre & .542 & .571 & .409 & .17 \\
\hline Denoix de Saint Marc & .542 & .571 & .409 & .17 \\
\hline Dumas & .452 & .375 & .556 & .255 \\
\hline Dutheillet & .551 & .535 & .714 & 201 \\
\hline Faure & .345 & .333 & .4 & .785 \\
\hline Giscard d'Estaing & .6 & .645 & .357 & .044 \\
\hline Guena & .534 & .444 & .582 & 185 \\
\hline Guillenchmidt & .543 & .547 & .5 & .757 \\
\hline Haenel & .507 & .556 & 409 & .267 \\
\hline Joxe & .563 & .547 & .714 & .233 \\
\hline Lancelot & .508 & .357 & .549 & 209 \\
\hline Lenoir & 494 & .36 & .558 & .107 \\
\hline Maestracci & 333 & & .333 & . \\
\hline Mazeaud & .543 & .5 & .61 & 187 \\
\hline Pelletier & .554 & 441 & .677 & .057 \\
\hline Pezant & .56 & .56 & & \\
\hline Robert & .355 & .36 & .333 & .906 \\
\hline Rudloff & .25 & .25 & & . \\
\hline Schnapper & .536 & .518 & .714 & .163 \\
\hline Steinmetz & .548 & .555 & .462 & .519 \\
\hline Veil & .55 & .505 & .617 & .181 \\
\hline
\end{tabular}

Note: Missing values are due to the fact that some Justices served only under left-wing or right-wing legislatures. 


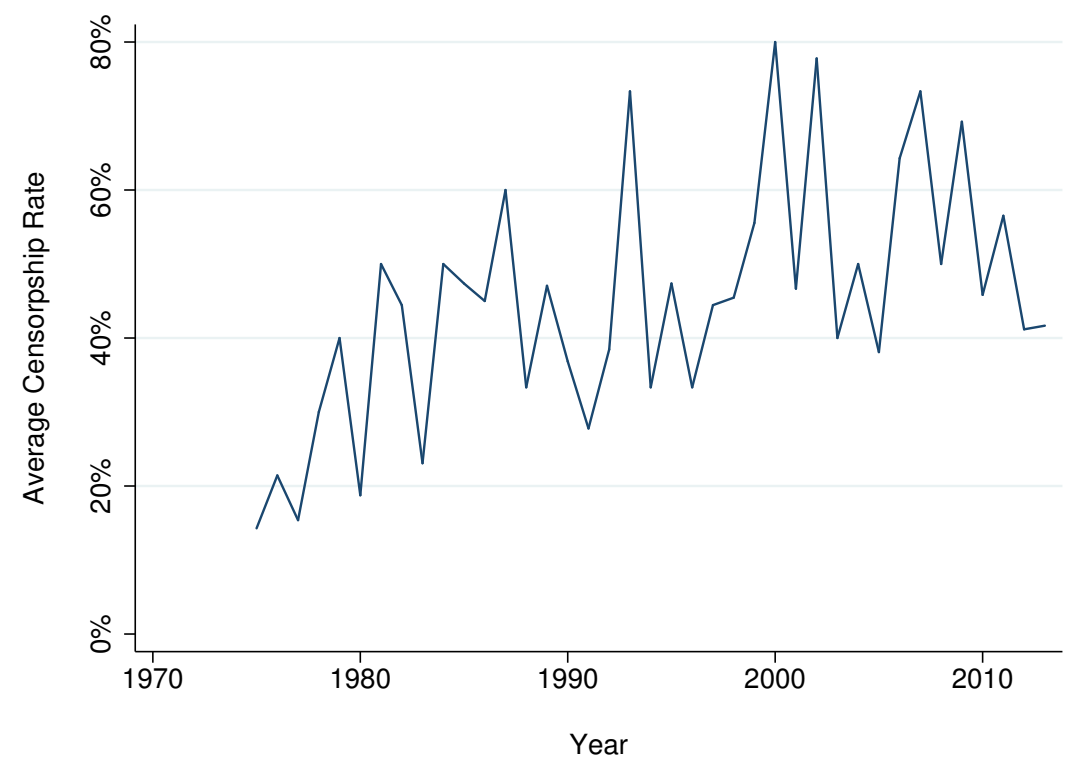

Figure 1: Average Censorship Rate per year since 1974

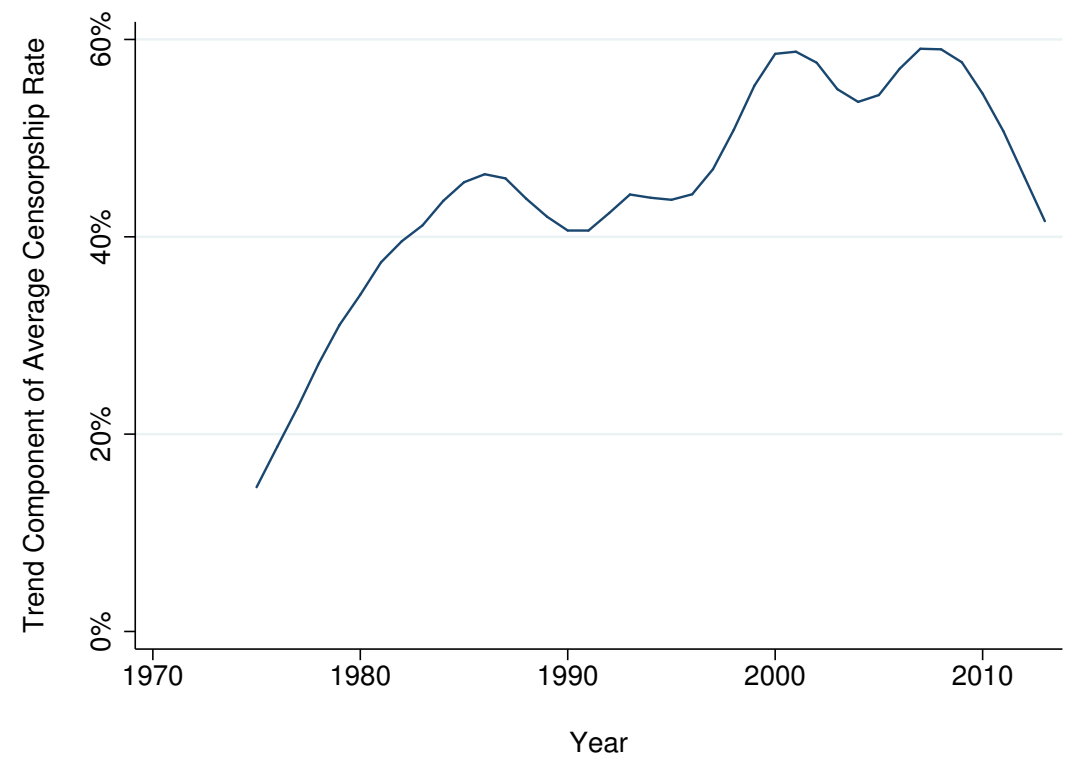

Figure 2: Trend Component of the Censorship Rate per year since 1974 


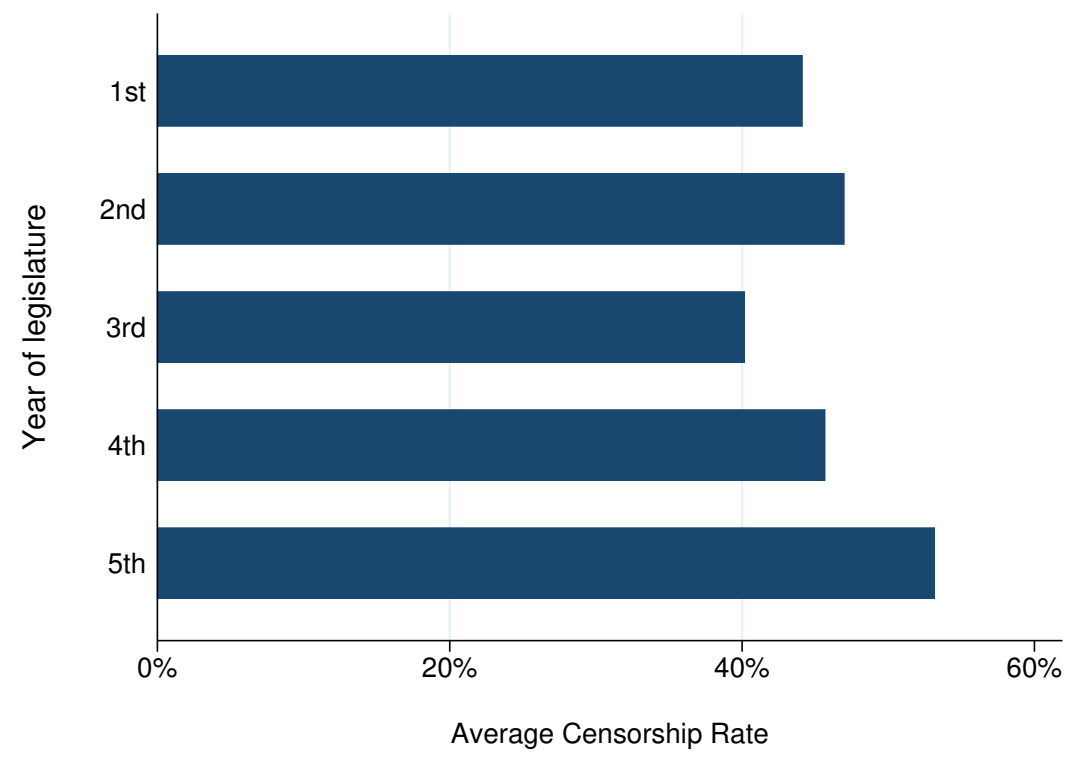

Figure 3: Average Censorship Rate per Year of Legislature

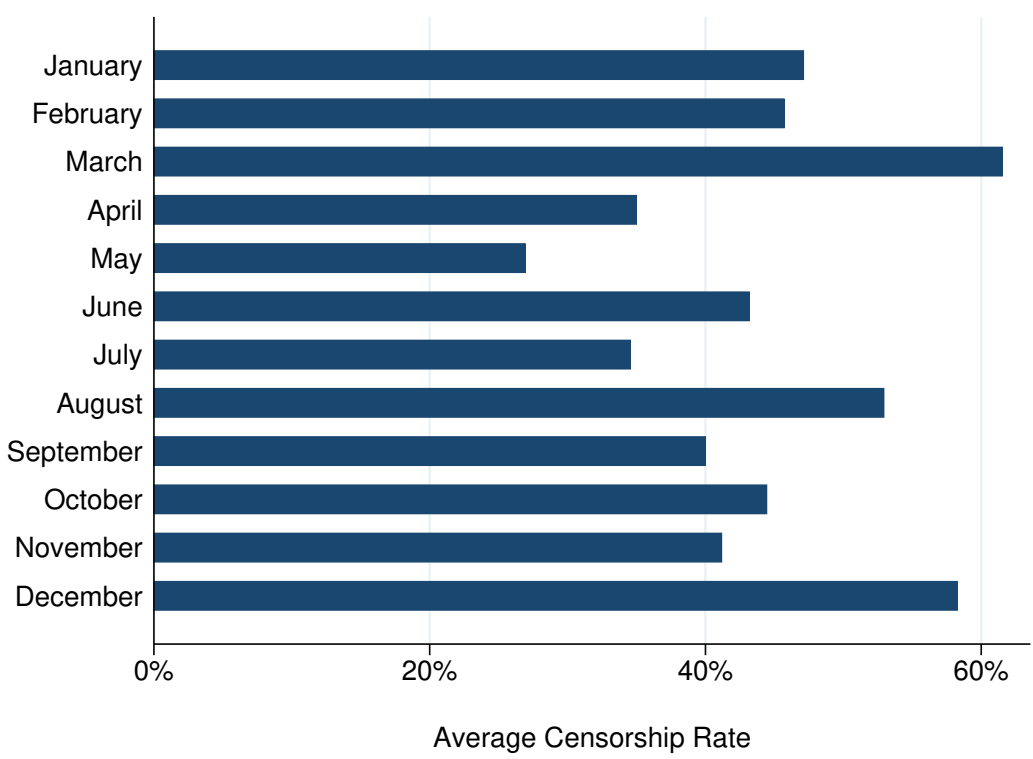

Figure 4: Average Censorship Rate per Month 


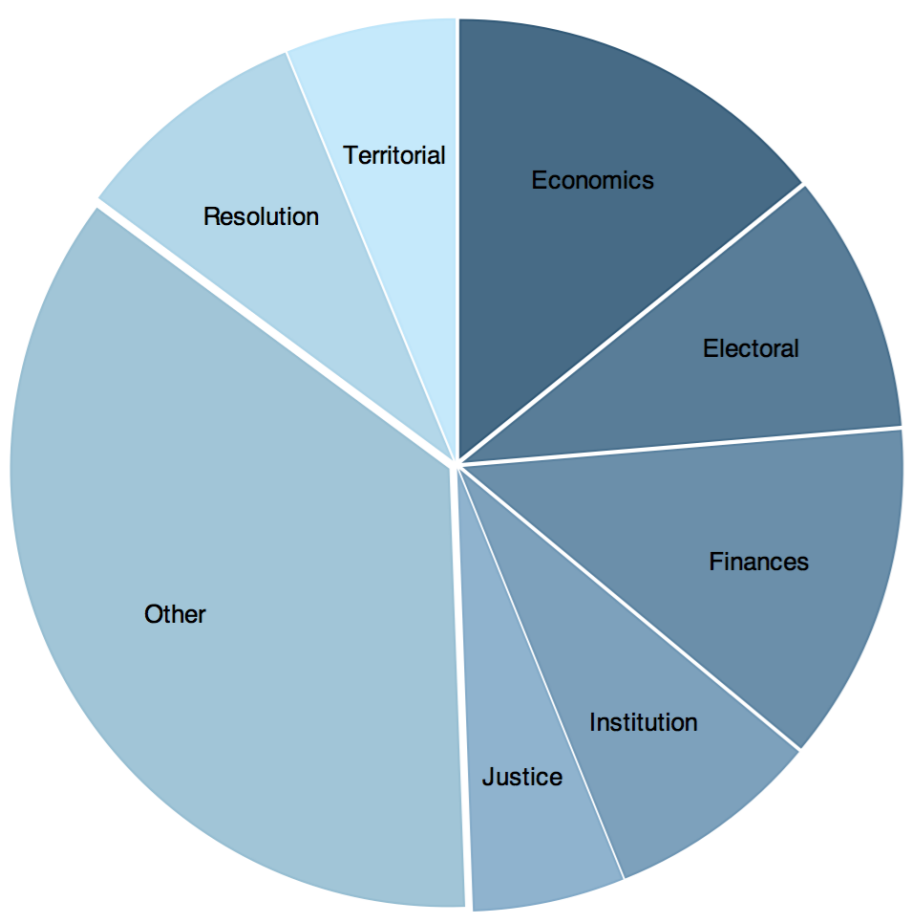

Figure 5: Composition of Challenged Laws.

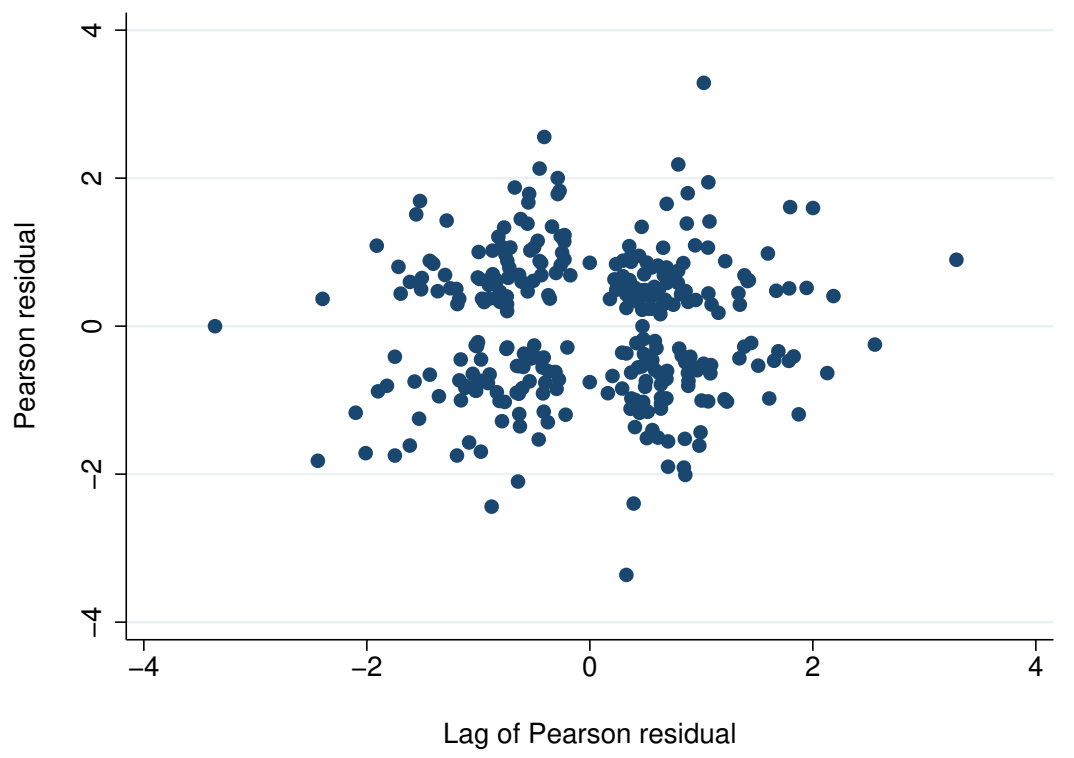

Figure 6: Plot of residuals and lag residuals. 


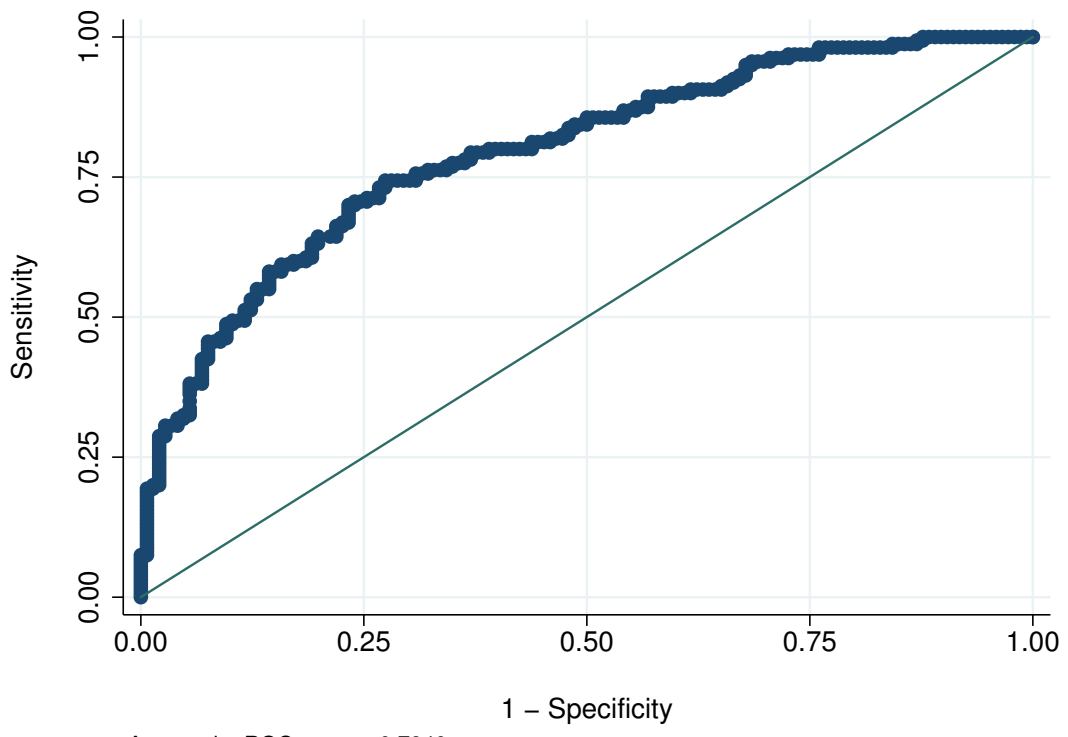

Area under ROC curve $=0.7940$

Figure 7: ROC curve analysis.

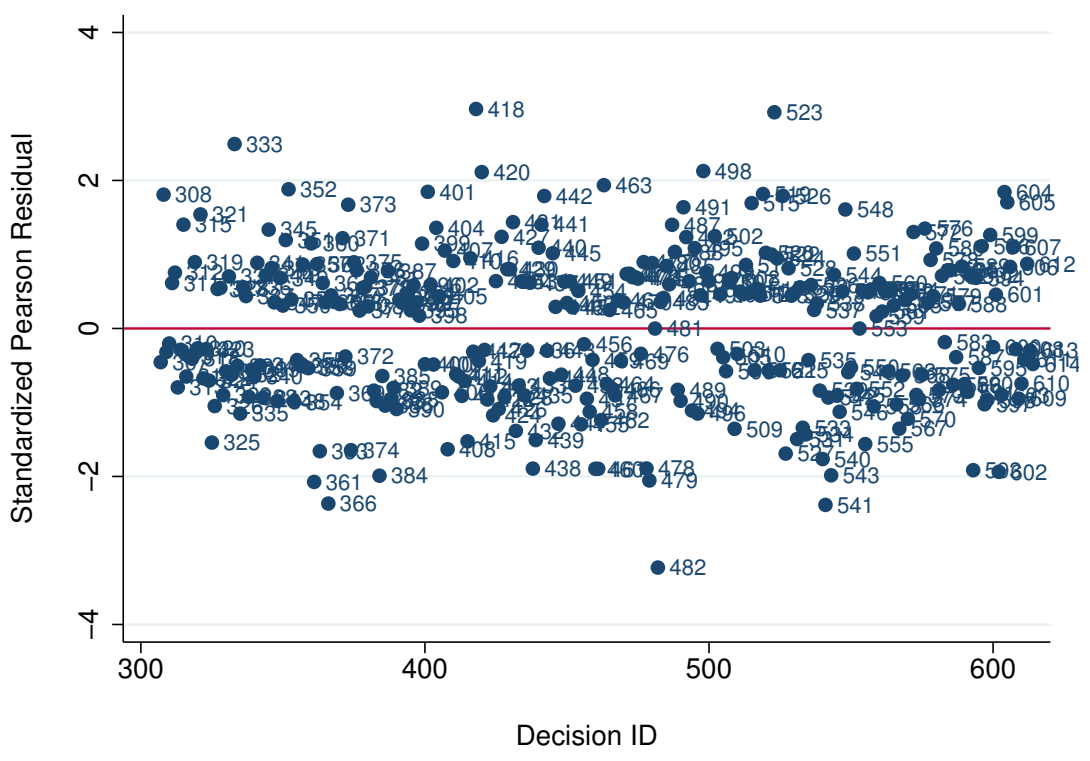

Figure 8: Standardized Pearson Residuals. 


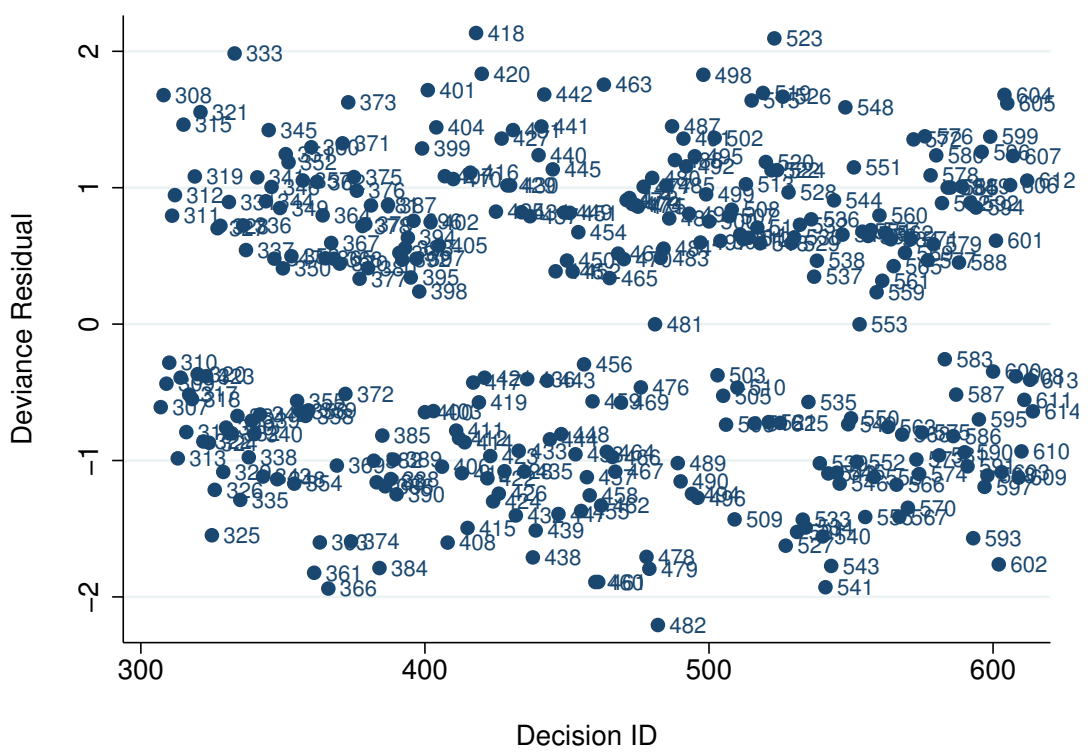

Figure 9: Deviance Residuals.

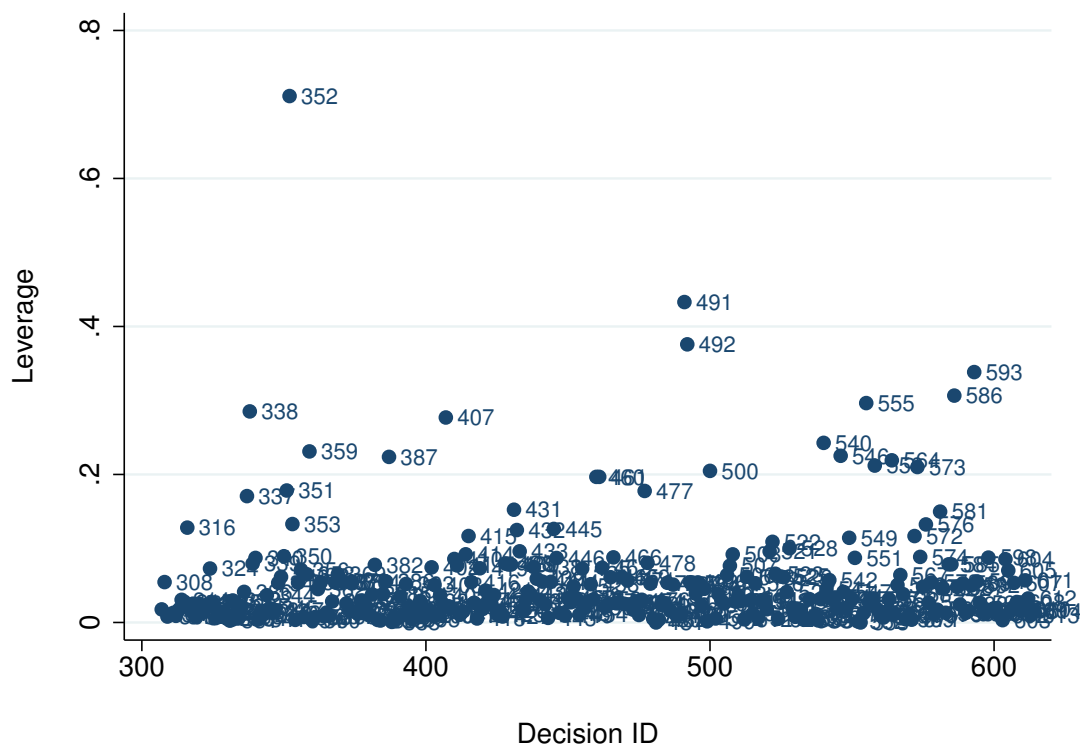

Figure 10: Leverage. 


\section{References}

Amaral-Garcia, S., Garoupa, N. and Grembi, V. (2009), 'Judicial Independence and Party Politics in the Kelsenian Constitutional Courts: The Case of Portugal', Journal of Empirical Legal Studies 6(2), 381-404.

Balli, H. O. and Sørensen, B. E. (2012), 'Interaction Effects in Econometrics', Empirical Economics 45(1), 583-603.

Cameron, C. M. and Kornhauser, L. (2010), 'Modeling Collegial Courts: Adjudication Equilibria', Working Paper.

Carroll, R. and Tiede, L. (2011), 'Judicial behavior on the Chilean constitutional tribunal', Journal of Empirical Legal Studies 8(4), 856-877.

Epstein, L. and Landes, W. M. (2012), 'Was There Ever Such a Thing as Judicial Self-Restraint?', California Law Review 100, 557-578.

Epstein, L., Landes, W. M. and Posner, R. A. (2011), 'Why (and When) Judges Dissent', Journal of Legal Analysis 3(101-137).

Epstein, L. and Martin, A. D. (2012), 'Is the Roberts Court Especially Activist? A Study of Invalidating (and Upholding) Federal, State, and Local Laws', Emory Law School 61, 737-758.

Epstein, L., Martin, A. D., Quinn, K. M. and Segal, J. A. (2007), 'Ideological Drift Among Supreme Court Justices: Who, When, and How Important?', Northwestern University Law School 101(4), 1483-1541.

Epstein, L., Segal, J. A. and Spaeth, H. J. (2001), 'The Norm of Consensus on the U.S. Supreme Court', American Journal of Political Science 45(2), 362-377.

Feld, L. P. and Voigt, S. (2003), 'Economic Growth and Judicial Independence: Cross-Country Evidence Using a New Set of Indicators', European Journal of Political Economy 19, 497-527.

Franck, R. (2009), 'Judicial independence under a divided polity: A study of the rulings of the French constitutional court, 1959-2006', Journal of Law, Economics and Organization 25(1), 262-284.

Franck, R. (2009), 'Judicial Independence and the Validity of Controverted Elections', American Law and Economics Review 12(2), 423-461.

Garoupa, N., Gomez-Pomer, F. and Grembi, V. (2011), 'Judging Under Political Pressure: An Empirical Analysis of Constitutional Review Voting in the Spanish Constitutional Court', Journal of Law, Economics and Organization 29(3), 513-534.

Garoupa, N. and Grembi, V. (2013), Judicial Review and Political Bias: Moving from Consensual to Majoritarian Voting. Working Paper-2013.

Haynie, S. L. (1992), 'Leadership and Consensus on the U.S. Supreme Court', The Journal of Politics 54(4), 1158-1169. 
Hayo, B. and Voigt, S. (2007), 'Explaining de Facto Judicial Independence', International Review of Law and Economics 27, 269-290.

Hayo, B. and Voigt, S. (2013), 'Endogenous Constitutions: Politics and Politicians Matter, Economic Outcomes Don't', Journal of Economic Behavior and Organization 88, 47-61.

Hoennige, C. (2009), 'The electoral connection: How Pivotal Judge Affects Oppositional Success at European Constitutional Courts', West European Politics 32(5), 963-984.

Holcombe, R. G. and Rodet, C. S. (2012), 'Rule of Law and the Size of Government', Journal of Institutional Economics 8, 49-69.

La Porta, R. and Lopez-de-Silanes, F. and Shleifer, A. and Vishny, R., C. S. (1999), 'The Quality of Government', Journal of Law, Economics and Organization 15, 222-279.

Lijphart, A. (1999), Patterns of Democracy, Yale University Press.

Martin, A. D., Quinn, K. M. and Epstein, L. (2005), 'The Median Justice on the United States Supreme Court', North Carolina Law Review 83(5), 1275-1320.

Melton, J. and Ginsburg, T. (2014), 'Does De Jure Judicial Independence Really Matter? A Reevaluation of Explanations for Judicial Independence', Journal of Law and Courts 2(2), 187217.

Miles, T. J. and Sunstein, C. R. (2008), 'The Real World of Arbitrariness Review', The University of Chicago Law Review $\mathbf{7 5}$.

Pellegrina, L. D. and Garoupa, N. (2013), 'Choosing Between the Government and the Regions: An Empirical Analysis of the Italian Constitutional Court Decisions', European Journal of Political Research 52.

Peng, C.-Y. and Lee, K. L. and Ingersoll, G. M (2002), 'An Introduction to Logistic Regression Analysis and Reporting', The Journal of Educational Research 96(1).

Ramseyer, J. M. and Rasmusen, E. B. (1997), 'Judicial Independence in a Civil Law Regime: The Evidence from Japan', Journal of Law, Economics and Organization 13(2), 259-286.

Schnapper, D. (2010), Une Sociologue au Conseil Constitutionnel, Editions Gallimard.

Shayo, M. and Zussman, A. (2011), 'Judicial Ingroup Bias in the Shadow of Terrorism', Quarterly Journal of Economics 126, 1447-1484.

Spiller, P. T. and Gely, R. (1992), 'Congressional Control or Judicial Independence: The Determinants of U.S. Supreme Court Labor-Relations Decisions, 1949-1988', RAND Journal of Economics 23(4), 463-492

Troper, M. (2007), 'Le réalisme en droit constitutionnel', Cahier du Conseil Constitutionnel 22 